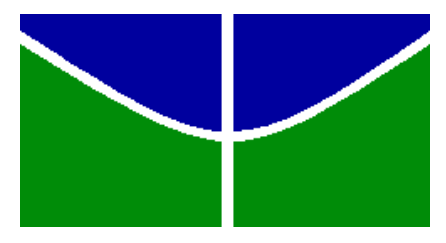

UNIVERSIDADE DE BRASÍLIA - UnB

Programa de Pós-Graduação em

Nanociência e Nanobiotecnologia

MARCOS ANTONIO FLORENTINO DE OLIVEIRA LEITE

ELABORAÇÃo DE CARVÃO MAGNÉTICO PARA REMOÇÃO DE BISFENOL A EM ÁGUAS CONTAMINADAS

BRASÍLIA - DF

2016

Universidade de Brasília 
Instituto de Ciências Biológicas

Programa de Pós-Graduação em Nanociência e Nanobiotecnologia

MARCOS ANTONIO FLORENTINO DE OLIVEIRA LEITE

\section{ELABORAÇÃO DE CARVÃO MAGNÉTICO PARA REMOÇÃO DE BISFENOL A EM ÁGUAS CONTAMINADAS}

Dissertação apresentada ao programa de Pós-Graduação em Nanociências e Nanobiotecnologia, do Instituto de Ciências Biológicas da Universidade de Brasília, como parte integrante dos requisitos para obtenção do Título de Mestre em Nanociências e Nanobiotecnologia.

Orientador: Prof ${ }^{\circ}$. Dr. Marcelo Henrique Sousa

BRASÍLIA - DF 


\section{AGRADECIMENTOS}

Primeiramente, agradeço a Deus por ter me dado condições para que eu pudesse chegar até este presente momento.

Agradeço ao meu orientador Professor Doutor Marcelo Henrique Sousa por todo suporte, dedicação e brilhante empenho para a conclusão deste projeto.

À minha família por ser a base de tudo. Pois, sem ela, não encontraria forças para ser uma pessoa melhor a cada dia. Ao meu pai Antonio e minha mãe, carinhosamente chamada de Nina, que se esforçaram durante a vida e me deram asas para que eu pudesse conquistar o conhecimento que não poderá ser de mim retirado. Aos meus irmãos Camila e Marcelo por toda paciência e apoio.

À minha noiva Maria Viviane por toda compreensão, amor, paciência e companheirismo.

Aos meus amigos e colegas de laboratório: Senhor Telles, Renata e Diego Dias, por toda compreensão, colaboração e empenho para que eu pudesse concluir esse projeto.

Ao Professor Doutor Juliano Chaker por todo apoio e colaboração prestada.

Aos colegas de laboratório Gabriel, Katiúscia, Marcelo Parise e Mack pelo apoio e colaboração na parte experimental do projeto.

Ao Professor Vinícius pela paciência ao me ajudar na manipulação do UV-VIS.

À Faculdade e aos funcionários da Faculdade de Ceilândia (FCE) que prestaram o seu apoio logístico para a conclusão deste projeto.

A todos que direta ou indiretamente, fizeram parte e prestaram a sua contribuição para que eu concluísse este trabalho. 
Só há duas maneiras de viver a vida: a primeira é vivê-la como se os milagres não existissem. A segunda é vivê-la como se tudo fosse milagre

Albert Einstein 


\section{RESUMO}

Os recursos hídricos, na atualidade, demandam por soluções de remediação ambiental visando uma melhor qualidade de vida da população. Somando essa realidade ao fato que, nas últimas décadas, vem crescendo o número de publicações científicas relatando a incidência de disfunções no sistema endócrino de seres humanos e animais provocadas por substâncias tóxicas encontradas na água, surge a necessidade de buscar soluções ecológicas menos agressivas ao meio ambiente e à sociedade como um todo. $\mathrm{O}$ bisfenol A (BPA), conhecido composto de nome 2,2-bis (4-hidroxifenil) propano, funciona como um desses desreguladores endócrinos mais presentes no ambiente. Diversos trabalhos associam seus efeitos a problemas relacionados com doenças cardiovasculares, obesidade, carcinogenicidade, neurotoxicidade, problemas de desenvolvimento, entre outros. Nessa direção, este trabalho procurou desenvolver um carvão magnético capaz de adsorver o BPA contaminante, extraído-o do meio aquoso com a máxima eficiência. O carvão adsorvente foi caracterizado pelas de técnicas de microscopia de varredura (MEV), difração de raios X (DRX), dosagem em ICP - OES, magnetização (MAG) e medidas da área de superfície através do BET (BrunauerEmmett-Teller). Os testes de adsorção revelaram que a remoção de BPA pelos carvões ativados tendem pela isoterma de Freundlich e a cinética de adsorção pela pseudo de segunda ordem. O estudo também revelou que parâmetros como tamanho e o volume dos poros dos carvões adsorventes influenciaram na capacidade de adsorção e na cinética dos mesmos. Os resultados demonstraram-se bastante satisfatórios com uma eficiência de remoção de 99,3\%.

Palavras chaves: bisfenol A, remediação ambiental, carvões magnéticos, desreguladores endócrinos 


\begin{abstract}
Actually water resources look for environmental remediation solutions to a better life quality of the population. This reality is added to the fact that the last decades has been increasing the number of research reporting about disorders in the humans' and animals' endocrine systems caused by toxic substances found in the water, less harmful ecological solutions to treat the environment need to be put into practice. Bisphenol A (BPA), also is known like 2,2-bis (4-hydroxyphenyl) propane, it acts as one of these endocrine disrupters longer present in the environment. Several studies associate their effects and problems related to cardiovascular disease, obesity, carcinogenicity, neurotoxicity, developmental problems, and others. This study's worked with developing a magnetic carbon capable of adsorbing the contaminant BPA, it is extracted from the aqueous with the maximum efficiency. The adsorbent carbon was characterized by scanning microscopy, X-ray diffraction, ICP - OES dosage, magnetization and measurement of surface area by the BET (Brunauer-Emmett-Teller). Adsorption tests showed that the removal of the BPA by activated carbons with Freundlich's isotherm and the adsorption kinetics and the pseudo second order. It also showed that parameters as size and volume of adsorbent pores influence their adsorption capacity and kinetic. The results proved efficiency of $99.3 \%$ and allowed the satisfactory with the almost removal.
\end{abstract}

Key words: Bisphenol A; Environmental Remediation; Magnetic Coals; Endocrine Disruptors. 


\section{LISTA DE FIGURAS}

Figura 1 - Representação de estrutura do BPA e de hormônios endócrinos: estradiol e dietilestilbestrol.

Figura 2 - Bisfenóis análogos derivados de alguns outros produtos ou resultantes de poluição.

Figura 3 - processo de elaboração do carvão magnético: em (1) ocorre a mistura do carvão com meio aquoso; Em (2) adição da solução de $\mathrm{Fe}^{2+}$ e $\mathrm{F}^{3+}$ na solução 1; Em (3) adição de $\mathrm{NaOH}$ completando o processo de formação da magnetita $\left(\mathrm{Fe}_{3} \mathrm{O}_{4}\right)$.

Figura 4 - Imagem do carvão ativado sem o $\mathrm{Fe}_{3} \mathrm{O}_{4}$ impregnado e carvão magnético CAMG produzido após elaboração.

Figura 5 - Representação esquemática do preparo da solução padrão $100 \mathrm{mg} / \mathrm{L}$ de BPA.

Figura 6 - Tipos de agitações utilizadas: agitação por vórtex e agitação por tombamento.

Figura 7 - Foto da adição de partículas para realização do estudo de adsorção. Figura 7-A: imagem das amostras contaminadas com BPA em tubos falcon; Figura 7-B: amostra de carvão magnético (CAMG A) dentro de um tubo falcon. Figura 7-C: pesagem de pequenas quantidades de massa de CAMG A. Figura 7D: adição de CAMG A para realização do estudo de eficiência de remoção nas amostras contaminadas.

Figura 8 - Foto da adição de partícula nas soluções com BPA para o teste de pH.

Figura 9 - Difratograma dos carvões ativados A e B e, dos carvões magnéticos CAMG A e CAMG B.

Figura 10 - imagens de microscopia eletrônica de varredura - MEV. Em 10-A, 10-B e 10-C, são apresentadas as micrografias do carvão A nas ampliações de 5.000. 30.000 e 100.000 vezes, respectivamente. Em 10-D, 10-E e 10-F, são mostradas as micrografias do carvão B nas ampliações de 5.000, 30.000 e 100.000 vezes, respectivamente.

Figura 11 - imagens de microscopia eletrônica de varredura - MEV. Nas imagens 11-A, 11-B e 11-C, são apresentadas as micrografias do CAMG A nas magnitudes de 30.000, 100.000 e 200.000 vezes, respectivamente. E nas imagens 11-D, 11-E e 11-F, são mostradas as micrografias do CAMG B nas magnitudes de 30.000, 100.000 e 200.000 vezes, respectivamente. 
Figura 12 - A) Curva de magnetização versus campo magnético aplicado para as amostras de CAMG A e CAMG B. B) O gráfico em detalhe mostra a histerese a baixo campo.

Figura 13 - Gráfico de isotermas de adsorção/dessorção de $\mathrm{N}_{2}$ para o carvão A e o CAMG A.

Figura 14 - Gráfico de Isotermas de adsorção/dessorção de $\mathrm{N}_{2}$ para o carvão B e o CAMG B.

Figura 15 - Distribuição de poro por volume - Carvão A e CAMG A.

Figura 16 - Distribuição de poro por volume - Carvão B e CAMG B.

Figura 17 - Gráfico mostrando as absorbâncias do BPA puro em diferentes pHs e uma inserção no canto superior direito, mostrando a relação de absorbâncias em diferentes comprimentos de onda $(\lambda)$ para todos os $\mathrm{pHs}$ medidos.

Figura 18 - Calibração utilizando a solução padrão de BPA. Também encontramos um insert no canto inferior direito da figura mostrando os parâmetros de regressão e seus respectivos erros: o coeficiente linear $(\mathrm{A})=$ $0,00158 \pm 5,16 \mathrm{E}^{-4}$ e intercepto $(\mathrm{B})=0,01418 \pm 2,18 \mathrm{E}^{-5} ; \mathrm{R}^{2}=0,9999$.

Figura 19 - Gráfico de eficiência de remoção em função do $\mathrm{C}_{\mathrm{np}}$.

Figura 20 - Gráfico da capacidade de adsorção $\left(q_{e}\right)$ em função da concentração em equilíbrio $\left(C_{e}\right)$ na solução de BPA.

Figura 21 - Gráfico da eficiência de remoção utilizando os carvões CAMG A e CAMG B.

Figura 22 - Isotermas de adsorção de Langmuir e Freundlich para os carvões magnéticos CAMG A e CAMG B.

Figura 23 - Cinética de adsorção (tempo de contato) para os modos de agitação em vórtex e tombamento.

Figura 24 - Gráfico da cinética de adsorção para os carvões magnéticos CAMG A e CAMG B.

Figura 25 - Gráfico da eficiência de remoção em função do pH. 
Figura 26 - Especiação para as formas protonada e desprotonada da molécula de BPA.

Figura 27 - Demonstração das interações de van der Wals entre o BPA e o carvão magnético. 


\section{LISTA DE TABELAS}

Tabela 1 - Especificações técnicas de reagentes.

Tabela 2 - Técnicas utilizadas para caracterização e análises de adsorção.

Tabela 3 - Análise de ICP - OES.

Tabela 4 - Valores de área superficial e de volume de microporos de cada carvão ativado e carvão magnético trabalhados.

Tabela 5 - Parâmetros de remoção na agitação vórtex.

Tabela 6 - Parâmetros de remoção para a agitação tombamento.

Tabela 7 - Parâmetros para utilizado pelos modelos de Langmuir e Freundlich.

Tabela 8 - Parâmetros de remoção para o CAMG A na agitação tombamento.

Tabela 9 - Parâmetros de remoção para o CAMG B na agitação tombamento.

Tabela 10 - Parâmetros de análise para os modelos de Langmuir e Freundlich para o CAMG A e o CAMG B.

Tabela 11 - Tempo de contato entre o CAMG e a solução de BPA.

Tabela 12 - Parâmetros de tempo de contato para os carvões CAMG A e CAMG B. 


\section{LISTA DE ABREVIATURAS E SIGLAS}

ASTM

BET

BPA

BPF

CA

CAG

CAMG

CAMG A

CAMG B

CAP

CDE

CDEs

$\mathrm{Cl}_{\mathrm{x}} \mathrm{BPA}$

DBD

DE

DEs

DRX

ICP - OES

MAG

MEV

MIP

MMIP

UV-VIS

VSM
American Society for Testing Materials.

Brunauer-Emmett-Teller.

Bisfenol A.

Bisfenol F

Carvão ativado.

Carvão ativado granular.

Carvão Magnético.

Carvão Magnético A.

Carvão Magnético B

Carvão ativado em pó.

Composto desregulador endócrinos.

Compostos desreguladores endócrinos.

BPA Cloro derivados.

Descarga de barreira dielétrica.

Desregulador endócrino.

Desreguladores endócrinos.

Difração de raios X.

Espectrometria de emissão atômica com plasma indutivamente acoplado.

Magnetização.

Microscopia eletrônica de varredura.

Polímeros molecularmente impressos.

Polímeros molecularmente impressos magnéticos.

Ultravioleta-visível

Vibrating Sample Magnetometer. 


\section{SUMÁRIO}

1. INTRODUÇÃ

1.1 Desreguladores Endócrinos.................................................................................... 2

1.2 BPA e toxicidade..................................................................................................... 3

1.3 BPA e poluição...................................................................................................................... 4

1.4 Métodos de remoção.............................................................................................. 5

1.4.1 Método de remoção por adsorção usando MIPs ...................................... 6

1.4.2 Remoção por adsorção utilizando carvão ativado........................................ 7

1.4.3 Remoção por adsorção utilizando carvão magnético................................... 8

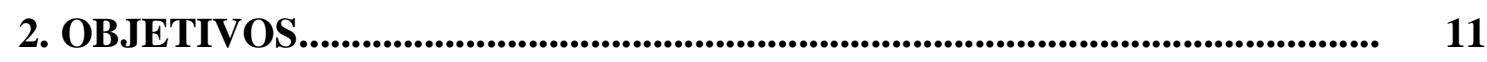

2.1 Geral............................................................................................................................... 11

2.2 Específicos.............................................................................................................. 11

3. MATERIAIS E MÉTODOS.................................................................................. 12

3.1 Elaboração e caracterização..................................................................... $\quad 12$

3.1.1 Método de preparação dos carvões magnéticos........................................... $\quad 12$

3.1.2 Caracterização ........................................................................................................ 14

3.1.2.1 Instrumentação............................................................................ 14

3.1.2.2 Determinação da estrutura cristalina por difração de raios $X-D R X$.. $\quad 16$

3.1.2.3 Estudo da morfologia e textura por microscopia eletrônica de varredura - MEV ..................................................................................................

3.1.2.4 Determinação do teor de ferro por espectrometria de emissão atômica com plasma indutivamente acoplado (ICP-OES)

3.1.2.5 Magnetização por magnetometria de amostra vibrante - VSM.............. 18

3.1.2.6 Análise porosimétrica e da área superficial por BET - BrunauerEmmett-Teller. 
3.2 Estudos para avaliação de remoção de BPA

3.2.1 Metodologia para determinação de BPA em amostras aquosas.

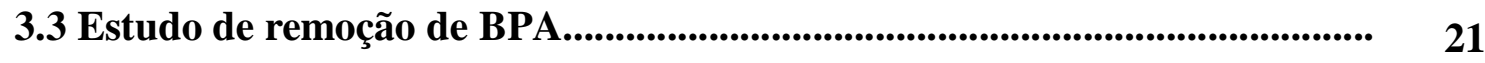

3.3.1 Estudo Cinético (tempo de contato)................................................................ 23

3.3.2 Estudo de influência do pH............................................................................... 23

4. RESULTADOS E DISCUSSÃO_............................................................... 24

4. 1 Caracterização do Carvão Magnético (CAMG) ............................................. 24

4.1.1 Determinação da estrutura cristalina por difração de raios X (DRX).... $\quad 25$

4.1.2 Dosagem de $\mathrm{Fe}_{3} \mathrm{O}_{4}$ por ICP-OES..................................................................... 26

4.1.3 Determinação da morfologia e textura por Microscopia Eletrônica de

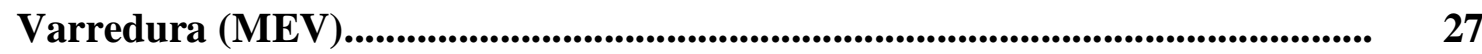

4.1.4 Magnetização por magnetometria de amostra vibrante - VSM................ 31

4.1.5 Análise porosimétrica e área superficial por BET - Brunauer-Emmett-

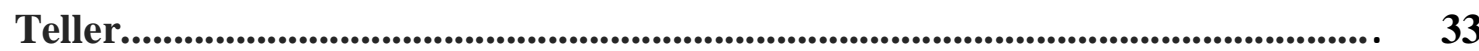

4.2 Metodologia para Determinação de BPA em amostras padrão..................... $\quad 36$

4.2.1 Construção da curva de calibração para o BPA........................................... $\quad 38$

4.3 Estudos de remoção por adsorção...................................................................... 39

4.3.1 Isotermas de Adsorção (Efeito da Agitação)................................................. 39

4.3.2 Isotermas de Adsorção (comparação entre CAMG A e CAMG B)........... 44

4.3.3 Cinética de Adsorção (Efeito da Agitação)................................................... 47

4.3.4 Cinética de Adsorção (Tempo de contato entre o BPA e os carvões

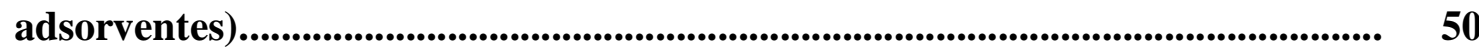

4.4 Influência do pH..................................................................................................... 53

5. CONCLUSÃO

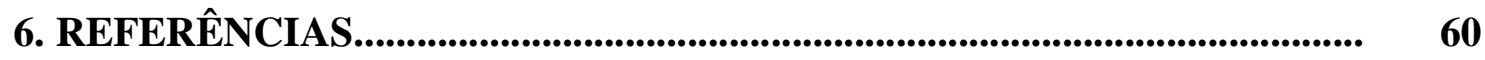




\section{INTRODUÇÃO}

A fabricação de produtos químicos tem aumentado drasticamente nas últimas décadas, o que vem elevando consideravelmente a propagação de tóxicos persistentes que podem se acumular dentro dos organismos. Particularmente, algumas destas substâncias exógenas podem interferir no sistema endócrino e nas funções fisiológicas de hormônios, agindo, principalmente, como compostos desreguladores endócrinos (CDE) e trazendo disfunções ao sistema endócrino e reprodutivo de seres humanos e animais, abortos espontâneos, distúrbios metabólicos e, até mesmo, incidência de neoplasias malignas ${ }^{1}$.

O bisfenol A (BPA), de nome científico 2,2-bis (4-hidroxifenil) propano (figura 1-a), é um desses CDEs e, é um intermediário químico largamente usado na síntese de policarbonato e resinas epoxi $\begin{array}{rrrrr}2 & 3 & 4 & 5 & 6\end{array}$. Policarbonatos são usados em recipientes de armazenamento de alimentos tais como garrafas de água e mamadeiras, enquanto que resinas epóxi são usadas como revestimento de superfície interna de recipientes de alimentos e bebidas e latas, a fim de proteger o alimento a partir do contato direto com o metal ${ }^{7}$.

Tendo em vista o amplo uso desse composto, diversos trabalhos vêm relacionando a exposição de seres humanos ao BPA - os níveis de BPA na urina dos adultos têm levado a um aumento da incidência de disfunção sexual em homens; o BPA está associado com doenças cardiovasculares, obesidade, carcinogenicidade, neurotoxicidade e problemas de desenvolvimento. De fato, a estrutura do monômero é análoga a de hormônios endócrinos, principalmente ao estradiol (figura 1-b) e dietilestilbestrol (figura 1-c), o que possibilita o BPA ligar-se aos receptores de estrógeno ${ }^{8}$. 


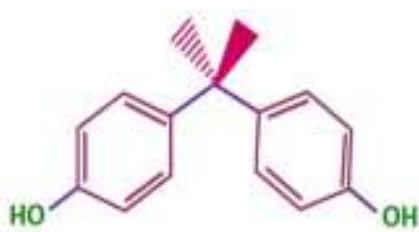

Bisphenol-A

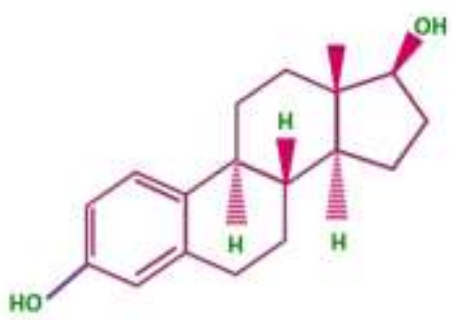

Estradiol

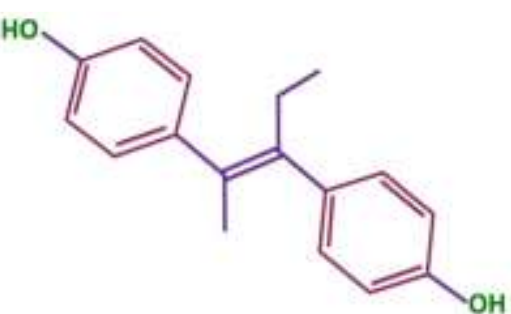

Diethylstilbestrol

$1-\mathrm{a}$

$1-\mathrm{C}$

Figura 1- Representação de estrutura do BPA (1-a) e de hormônios endócrinos: estradiol (1-b) e dietilestilbestrol (1-c) ${ }^{8}$.

Diante desses fatos, as agências reguladoras e departamentos de saúde em todo o mundo têm associado a exposição ao BPA um prejudicial efeito estrogênico sobre a saúde. Portanto, torna-se relevante o monitoramento e a redução dos níveis de concentração de BPA em diversos tipos de amostras, como as de efluentes e aquíferos, como prevenção aos seus nocivos efeitos.

\subsection{Desreguladores Endócrinos}

Desde o início do século XX, já existiam hipóteses prevendo alterações no funcionamento do sistema endócrino de algumas espécies animais expostas a substâncias químicas tóxicas. Atualmente, esta questão tem recebido atenção por parte da comunidade científica, principalmente devido ao número crescente de publicações relatando o aumento da incidência de disfunções no sistema endócrino de seres humanos e, mais significativamente, efeitos fisiológicos adversos observados em espécies animais para as quais a relação causa/efeito é mais evidente ${ }^{9}$. Desreguladores endócrinos (DEs) são poluentes que alteram o sistema endócrino e estão envolvidos na carcinogênese. Eles podem afetar a síntese, liberação e transporte de hormonas naturais, além de dentro dos tecidos-alvo, poder reduzir ou aumentar os efeitos em hormônios 
sobre os seus receptores e mudanças de sinalização. Quando a exposição ao DE acontece em períodos críticos da vida, desde embrião até a puberdade, podem agir em doses consideradas, até mesmo, seguras para um adulto. Além disso, os seus efeitos de epigenética também podem influenciar as gerações futuras ${ }^{10}$.

Vários químicos em atividade são suspeitos por provocarem esta desregulação, e abrangem uma gama de produtos naturais e sintéticos: hormônios, pesticidas, alquilfenóis, bisfenol A, ftalatos, dioxinas, compostos polifluoralquil, retardadores de chama bromados e metais pesados. O bisfenol A é o monômero que constitui o plástico policarbonato e, é utilizado também em resinas epóxi, além de ser usado como selante dental e também como aditivo para outros plásticos. Devido a isto, um elevado volume desta substância (mais que $2,5 \times 10^{6} \mathrm{Kg} /$ ano) é produzido mundialmente e talvez por essa razão seja o desregulador endócrino mais estudado ${ }^{11}$.

\subsection{BPA e toxicidade}

Atualmente, associa-se diversos efeitos toxicológicos ao BPA: um estudo realizado com células-tronco embrionárias de camundongos, in vitro, demonstrou que o BPA afeta a especilização de camadas germinativas durante o desenvolvimento embrionário, bem como o estabelecimento da ectoderma neural e células progenitoras neurais ${ }^{12}$; Ying et al. ${ }^{13}$ investigaram os efeitos da exposição ao BPA no miocárdio e mecanismos subjacentes de ratos machos e constataram que, durante um tempo prolongado de exposição, estes apresentaram cardiomepatia (caracterizada pela hipertrofia do miocárdio), comprometendo a função cardíaca e diminuindo a função mitocondrial respiratória. Outro estudo demonstrou que a exposição de ratos ao BPA podem causar problemas de localização espacial, aprendizagem e de memória ${ }^{14}$. Já 
Zhenxing et al. ${ }^{15}$ sugerem que a exposição ao BPA no início da vida pode resultar na transmissão de geração intolerância à glicose através da linha germinal do sexo masculino. Nessa direção, Fernández et al. realizaram um estudo que indicou uma associação estatisticamente significativa entre a exposição ao BPA e propil-parabeno e o risco de mau formações durante a gravidez ${ }^{16}$. A substância também apresenta efeitos relacionados a mamas durante o período gestacional. Em um estudo realizado com roedores, os animais expostos ao BPA apresentaram alterações no trato genital, apresentando pré-disposição ao carcinoma de células claras da vagina, bem como cancro da mama. Além disso, a exposição ao BPA durante o estudo induz alterações morfológicas tanto no estroma quanto no epitélio da glândula mamária fetal com 18 dias de idade $^{17}$.Os efeitos não são observados apenas em seres humanos ou animais, mas também em plantas que apresentaram algum tipo de modificação devido a ação do BPA. Em um estudo realizado com plantas de soja, Nie et al. identificaram que após a exposição de elevadas concentrações de BPA, as plantas apresentaram anomalias morfológicas evidentes e diminuições nos volumes e comprimentos de raízes ${ }^{18}$.

\subsection{BPA e poluição}

O papel dos desreguladores endócrinos como risco real para os ecossistemas, fauna e os seres humanos representa uma preocupação ${ }^{11}$. Um aspecto relacionado à poluição está na elevada reatividade do BPA com outros produtos domésticos. Entre os exemplos, seria a reação do cloro desinfetante na formação instantânea de derivados clorados $\left(\mathrm{Cl}_{\mathrm{x}} \mathrm{BPA}\right)$ em vários meios ambientais. O problema ocorre quando o BPA residual entra em contato com o cloro desinfetante da torneira ou algum produto de consumo doméstico, produzindo fontes de exposição $\mathrm{Cl}_{\mathrm{x}} \mathrm{BPA}$ e análogos de $\mathrm{BPA}$. $\mathrm{O}$ 
BPA halogenado possui atividade estrogênica potencializada. Derivados halogenados do BPA são amplamente utilizados como retardadores de chama e já existem estudos de bisfenóis análogos onde apontam concentrações consideráveis de BPF encontradas em rios no Japão, China, Coréia e India ${ }^{14}{ }^{19}{ }^{20}$. Uma das principais fontes de contaminação para os seres humanos correspondem as fontes alimentares. Em Taiwan, um grupo realizou um estudo para avaliar a dose média diária e o quociente de exposição ao BPA, avaliando a ingestão a longo prazo de BPA, bem como diferentes faixas etárias e sexo, e concluíram que uma combinação de várias vias de exposição a longo prazo da população pode ser motivo de preocupação no futuro ${ }^{21}$.

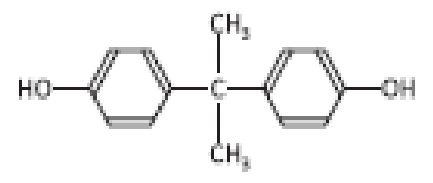

Bisphenol A (BPA)

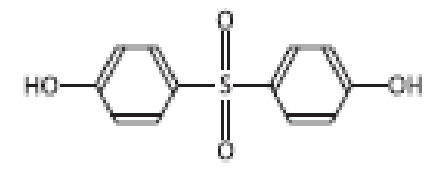

Bisphenol S (BPS)

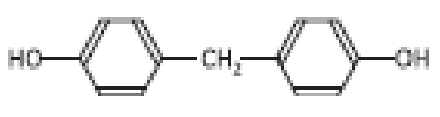

Bisphenol F (BPF)

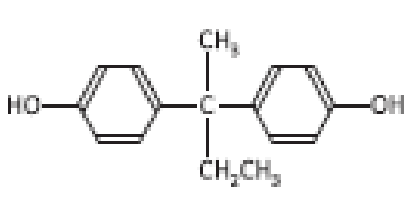

Bisphenol B (BPB)<smiles>CC(C)(c1ccc(O)cc1)c1ccc(C(C)(C)c2ccc(O)cc2)cc1</smiles>

Bisphenol P (BPP)<smiles>Oc1ccc(C2(c3ccc(O)cc3)CCCCC2)cc1</smiles>

Bisphenol Z (BPZ)

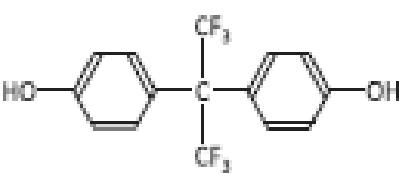

Bisphenol AF (BPAF)

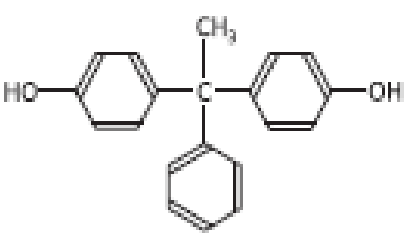

Bisphenol AP (BPAP)

Figura 2 - Bisfenóis análogos derivados de alguns outros produtos ou resultantes de poluição ${ }^{17}$.

\subsection{Métodos de remoção}

Não somente a detectação tem sido alvo de pesquisas, mas vários métodos têm sido desenvolvidos para a remoção do BPA de soluções aquosas, e amostras 
contaminadas, por exemplo, oxidação bioquímica, oxidação eletroquímica, ozonização, oxidação sonoquímica, destacando-se os processos fenton de oxidação avançada, com nanocatalisadores. Nessa direção, Huang et al. ${ }^{22}$ investigram a degradação de BPA utilizando catálise heterogênea sono-Fenton (Fenton combinado com ultra-som), utilizando nanopartículas magnéticas de $\mathrm{Fe}_{2} \mathrm{O}_{3}$. Yang et al $l^{23}$ utilizaram nanopartículas de ouro $(\mathrm{Au})$ dispersas em vários suportes de carbono, como catalisadores sólidos para degradarem moléculas de BPA em condições brandas. Além disso, Tsai et al. $^{24}$ utilizaram um reator de suspensão de dióxido de titânio $\left(\mathrm{TiO}_{2}\right)$ para fazer a fotodegradação de destruição de BPA em água.

\subsubsection{Método de remoção por adsorção usando MIPs (Polímeros molecularmente impressos)}

Técnicas de separação convencionais, tais como a coagulação, floculação e processos de precipitação, não são eficazes para a remoção de desreguladores endócrinos, especialmente aqueles de baixo peso molecular. Processos de separação avançada, tais como adsorção, filtração por membrana, e de troca iônica, normalmente mostram eficiência de remoção superiores (até 95\%), dependendo dos compostos testados 25 .

Os métodos de adsorção têm se mostrado bastante efetivos para levar a concentração de BPA a níveis inferiores ou iguais aos toleráveis pelas agências reguladoras. Diante disso, os polímeros molecularmente impressos (MIPs) podem apresentar-se como uma das opções para adsorção de BPA. Nessa perspectiva, Zhu et al. utilizaram MIPs como adsorventes seletivos para extração de BPA da água de um $\operatorname{lago}^{26}$.Yang et al. também conseguiram imprimir moléculas de BPA e outros bisfenóis 
em microesferas de polímeros que apresentaram boa capacidade de adsorção e seletividade específica para BPA e seus análogos demonstrada por HPLC. MIPs também podem ser combinados com outras técnicas, dentre elas, se destacam a associação com partículas magnéticas. Nesse sentido, Guo et al. sintetizaram polímeros molecularmente magnéticos (MMIPs) com base em caulinita compósitos $/ \mathrm{Fe}_{3} \mathrm{O}_{4} \mathrm{com}$ sucesso para a adsorção seletiva e a separação de BPA de soluções aquosas. Outro grupo de pesquisa conseguiu sintetizar polímeros de impressão molecular magnéticos (MMIPs) que apresentaram grande estabilidade magnética e seletivamente para moléculas de $\mathrm{BPA}^{27} 2829$.

Contudo, estes métodos exigem mostram-se trabalhosos e exigem técnicas dispendiosas como HPLC, que demandam mão de obra especializada. Portanto, surge a necessidade de uma metodologia menos elaborada e dispendiosa que permita uma síntese de adsorventes mais simples para a remoção de BPA de águas residuais.

\subsubsection{Remoção por adsorção utilizando carvão ativado}

Materiais carbonáceos como carvão ativado, nanotubos de carbono e óxido de grafeno têm chamado à atenção por causa da sua estabilidade química, grande área superficial, abundande distribuição de poro por tamanho e viabilidade de produção em $\operatorname{massa}^{30}$. Com bastante vantagem, o carvão ativado (CA), encontrado nas formas em pó e granular, se configura como um dos mais utilizados para essa aplicação. De fato, a capacidade do CA para adsorver um grande número (e em quantidades consideráveis) de substâncias químicas e de ser reciclado (particularmente o CAG - carvão ativado granular), demonstra que este material apresenta características muito eficazes e economicamente viáveis para o tratamento da água, incluindo a remoção de $\mathrm{BPA}^{31}$. 
Quando esses materiais são particulados na escala de dimensão submicrométrica e nanométrica, principalmente devido ao aumento da relação entre a área superficial e a massa das nanopartículas, há uma otimização na eficiência de remoção dos poluentes ${ }^{32}$.Por exemplo, Liu $\mathrm{G}$ et al. ${ }^{33}$ utilizaram dois carvões ativados comerciais que foram submetidos a tratamento ácido e térmico obtendo uma excelente capacidade de adsorção de BPA por grama de carvão. Em outro estudo, Tang S et al. ${ }^{34}$ utilizaram a combinação de carvão ativado granular com descarga de barreira dielétrica (DBD) por plasma para adsorção e degradação de BPA e, posterior reciclagem do CAG. Em outro trabalho, Ravi $\mathrm{S}$ et al. $^{35}$ apresentaram uma revisão com diversos trabalhos demonstrando avanços na síntese de vários nanomateriais de carbono a partir de recursos sustentáveis.

Entretanto, mesmo com essa elevada eficiência para remoção dos poluentes, o CA apresenta algumas restrições que limitam sua aplicabilidade, como a baixa densidade, que reflete na dificuldade de manipulação e recuperação, além da dificuldade de homogeneização, quando misturadas aos sistemas contaminados, culminando em perda do poder de adsorção do poluente e da reciclagem das nanopartículas ${ }^{36}$.

\subsubsection{Remoção por adsorção utilizando carvão magnético}

As limitações do carvão ativado, entretanto, podem ser minimizadas pela combinação deste material com nanomateriais magnéticos, a fim de se obter um sistema magneto-responsível que responde ao estímulo externo de um campo magnético e, assim, podem ser manipulados, direcionados e recuperados, mantendo as propriedades adsortivas do material adsorvedor ${ }^{37}$. É nessa direção que, além das numerosas aplicações já bastante conhecidas nos campos da medicina e tecnologia, as 
nanopartículas magnéticas (principalmente os óxidos de ferro) têm sido potencialmente utilizadas na área de reparação e tratamento ambiental, principalmente como adsorventes de metais pesados, de matéria orgânica e até mesmo de microorganismo ${ }^{38}$.Nesse processo, os contaminantes são normalmente adsorvidos na superfície quimicamente modificada de nanomateriais/nanocompósitos magnéticos e, com o auxílio de um campo magnético externo, são recuperados, reprocessados e reutilizados em nova descontaminação. Para remoção do BPA, a funcionalização dessas nanopartículas ou combinação com outros materiais tem sido de natureza variada, como com ácido dodecanoico ${ }^{39}$, ciclodextrina ${ }^{40}$,quitosana ${ }^{41}$, etc., mas compósitos como aqueles com CA têm recebido atenção especial ${ }^{42}$. Mais especificamente, associando as características das nanopartículas magnéticas com as de adsorção do carbono, foram desenvolvidos adsorventes de baixo custo que podem se ligar a contaminantes ambientais e posteriormente, ser separados magneticamente em contraste com adsorventes tradicionais que são separados por peneiramento ou decantação por gravidade $^{43}$.Outro aspecto a se ressaltar, é que a remoção de BPA torna-se mais difícil na presença de matéria orgânica natural (MON) quando se utiliza cavão ativado comum, isso devido à formação de compostos orgânicos complexos entre BPA e MON. Estudos anteriores já demonstraram a capacidade de óxidos de ferro de interagir com a matéria orgânica natural por diversos motivos entre eles a interação eletrostática, complexação de superfície, interação hidrofóbica, efeito entrópico, ligação de hidrogênio. Dessa forma, a necessidade de fabricar híbridos adsorventes de carvões ativados e óxidos de ferro que podem atingir simultaneamente a remoção de MON e BPA para uma gerência mais segura da água ${ }^{44}$.

Nessa direção, existem revisões bibliográficas que evidenciam o uso do carvão ativado magnético para a remoção de poluentes orgânicos e inorgânicos de águas 
residuais ${ }^{16}$. Variadas técnicas de síntese para a produção de carvão magnético como Kakavandi $\mathrm{B}$ et al. que sintetizaram nanopartículas magnéticas $\mathrm{Fe}_{3} \mathrm{O}_{4} /$ carvão ativado (CA-Fe $\left.\mathrm{O}_{4}-\mathrm{MNPs}\right)$ como um adsorvente para remoção de anilina de amostras residuais sintéticas de água ${ }^{45}$. Na busca por adsorventes de baixo custo para contaminantes ambientais, Mohan D. et al desenvolveram carvões a base de casca de amêndoas, que posteriormente, foram convertidos em carvões magnéticos para remoção de trinitrofenol de águas residuais ${ }^{23}$. Além disso, um estudo comparativo da capacidade de adsorção entre carvões ativados comerciais e biochars (carvão ativado sustentável produzido através da pirólise de matéria orgânica) foi realizado por Han $\mathrm{Z}$ et al, que com e sem magnetita impregnada, buscaram uma melhor compreensão do atributo magnético desejável, efeitos colaterais do magnetismo sobre a capacidade adsorvente e uma melhor avaliação no que diz respeito ao sentido técnico e econômico dos tratamentos aplicados ${ }^{14}$. Nessa direção ambiental, Li Z et al. utilizaram ferrita de cobalto $\left(\mathrm{CoFe}_{2} \mathrm{O}_{4}\right)$ induzida em carvão ativado em pó (CAP) por meio de uma rota química de solução-gel, para remoção de BPA em soluções aquosas ${ }^{46}$.

Recentemente, o método de separação magnética tem sido amplamente utilizado devido ao baixo custo, simplicidade e por apresentar rápida separação e alta eficiência. Além disso, a presença de óxido de ferro magnético $\left(\mathrm{Fe}_{3} \mathrm{O}_{4}\right)$ leva a estabilidade química, baixa toxicidade, e excelente capacidade de reciclagem de adsorvente. Devido a isto esta metodologia é utilizada amplamente para a remoção de íons tóxicos e contaminantes orgânicos de águas residuais ${ }^{24}$.

Diante desses aspectos, esse trabalho propõe a elaboração de carvão ativado modificado com nanopartículas magnéticas - com grande afinidade com o BPA - para remoção desse contaminante em água de efluentes e/ou para otimização de metodologias na determinação do BPA nessas amostras. 


\section{OBJETIVOS}

\subsection{Geral}

- Elaborar sistemas de partículas submicrométricas de carvão ativado, impregnadas com nanopartículas magnéticas, para remoção de BPA em amostras contaminadas.

\subsection{Específicos}

- Adaptar metodologias espectroscópicas já descritas na literatura para determinação de BPA em matrizes de recursos hídricos;

- Elaborar nanopartículas de magnetita por cooprecipitação química e impregnálas em amostras de carvão ativado comercial;

- Caracterizar as amostras sintetizadas por diversas técnicas;

- Testar a eficiência de remoção de BPA em amostras simuladas, contendo BPA e utilizando os carvões magnéticos; 


\section{MATERIAS E MÉTODOS}

A metodologia do trabalho envolveu a execução de três etapas bem definidas:

1) elaboração e caracterização do carvão magnético; 2) estabelecimento de método para determinação de BPA em meio aquoso e 3) testes de adsorção de BPA no carvão magnético em amostras aquosas.

\subsection{Elaboração e caracterização}

A tabela 1 abaixo apresenta os fornecedores e as especificações técnicas dos reagentes químicos utilizados.

\begin{tabular}{|c|c|c|c|c|}
\hline \multirow[t]{2}{*}{ Reagentes } & Fórmula & Peso & Teor & Marca \\
\hline & Molecular & Molecular & & \\
\hline Bisfenol-A(BPA) & $\mathrm{C}_{15} \mathrm{H}_{16} \mathrm{O}_{2}$ & $228,29 \mathrm{~g} / \mathrm{mol}$ & $\geq 99 \%$ & Sigma Aldrich® \\
\hline Carvão A (Carvão ativo) & $\mathrm{C}_{\mathrm{n}}$ & $12,01 \mathrm{~g} / \mathrm{mol}$ & & Synth® \\
\hline Carvão B (Carvão ativo) & $\mathrm{C}_{\mathrm{n}}$ & $12,01 \mathrm{~g} / \mathrm{mol}$ & & Sigma Aldrich ${ }^{\circledR}$ \\
\hline Cloreto Férrico & $\mathrm{FeCl}_{3} \cdot 6 \mathrm{H}_{2} \mathrm{O}$ & $270,30 \mathrm{~g} / \mathrm{mol}$ & $\leq 100 \%$ & Vetec ${ }^{\circledR}$ \\
\hline Sulfato Ferroso & $\mathrm{FeSO}_{4} .7 \mathrm{H}_{2} \mathrm{O}$ & $278,01 \mathrm{~g} / \mathrm{mol}$ & $99 \%$ & Dinâmica ${ }^{\circledR}$ \\
\hline Ácido Clorídrico & $\mathrm{HCl}$ & $36,46 \mathrm{~g} / \mathrm{mol}$ & $\geq 36,5 \%$ & Nuclear® \\
\hline Hidróxido de Sódio & $\mathrm{NaOH}$ & $40,00 \mathrm{~g} / \mathrm{mol}$ & $\geq 97 \%$ & Vetec ${ }^{\circledR}$ \\
\hline Etanol & $\mathrm{C}_{2} \mathrm{H}_{6} \mathrm{O}$ & $46,07 \mathrm{~g} / \mathrm{mol}$ & $\geq 99,8 \%$ & Vetec ${ }^{\circledR}$ \\
\hline
\end{tabular}

\section{Tabela 1 - Especificações técnicas de reagentes.}

\subsubsection{Método de preparação dos carvões magnéticos}

A síntese do carvão magnético (CAMG) foi preparada através do método modificado de Mohan D et al. ${ }^{47}$ (Figura 3). O método utilizou a impregnação de 
nanopartículas magnéticas em carvão ativado. Para tal, as nanopartículas magnéticas foram sintetizadas in-situ, pela co-precipitação do sulfato ferroso com cloreto férrico em meio alcalino e, em um meio rico em carvão ativado. Primeiramente, $10 \mathrm{~g}$ de carvão ativado (CA) foram adicionados a $500 \mathrm{~mL}$ de água ultrapura e mantido sob agitação (1). Enquanto isso, 0,067 mol de ferro trivalente $\left(\mathrm{Fe}^{3+}\right)$ foram misturados a 0,033 mol de ferro bivalente $\left(\mathrm{Fe}^{2+}\right)$ em $200 \mathrm{~mL}$ de água num béquer de $500 \mathrm{~mL}$. Também foram adicionados a esta solução $2,5 \mathrm{~mL}$ de $\mathrm{HCl}$, desta forma, produzindo a solução (2). Esta solução foi misturada ao carvão ativado aquoso preparado anteriormente e agitada vigorosamente por 15 minutos a $70^{\circ} \mathrm{C}$. Após este tempo, foi adicionada à mistura 500 mL de uma solução (3) de hidróxido de sódio $(\mathrm{NaOH}) 4$ mol/L e deixou-se sob agitação por duas horas.

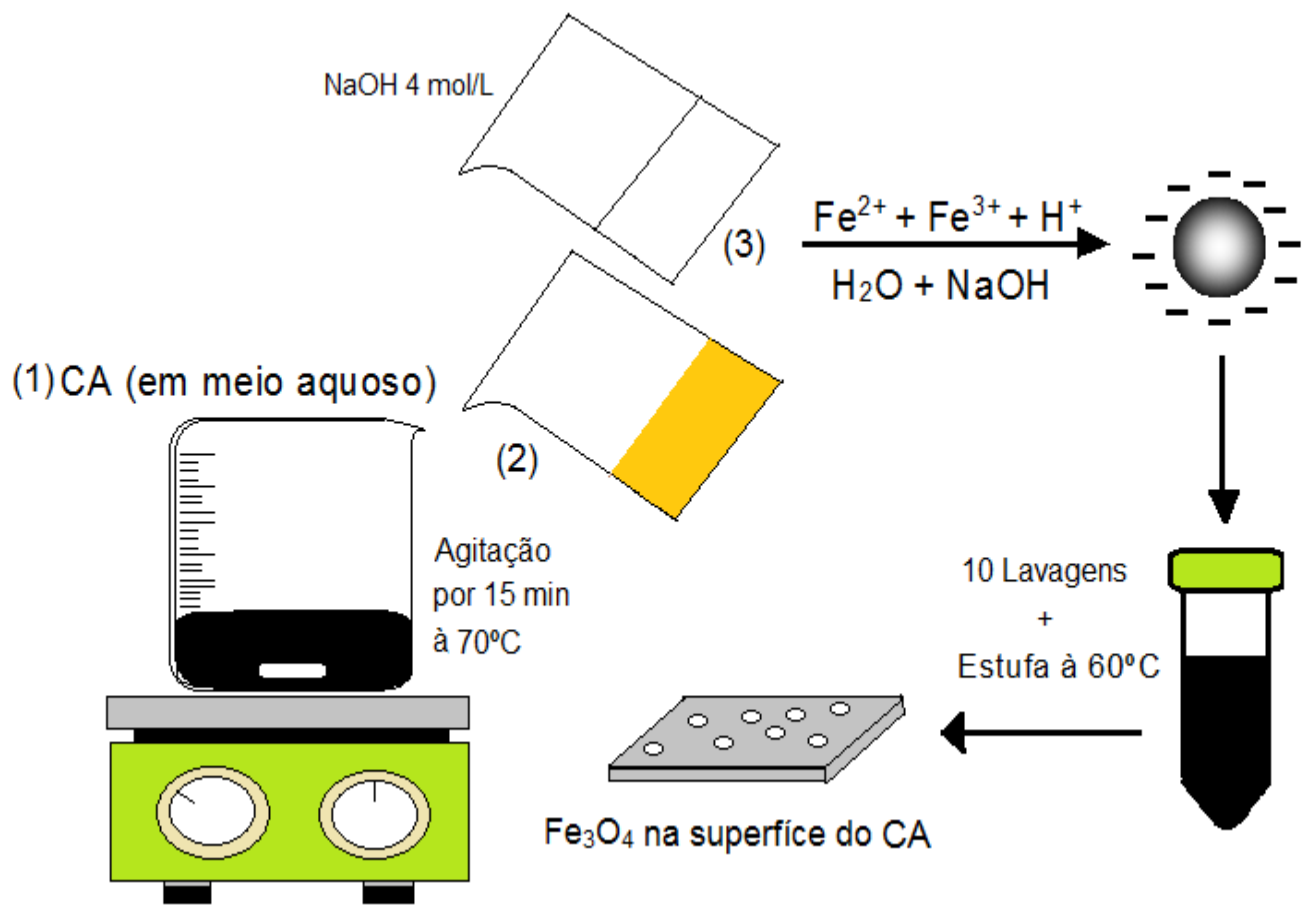

Figura 3 - processo de elaboração do carvão magnético: em (1) ocorre a mistura do carvão com meio aquoso; $\mathrm{Em}$ (2) adição da solução de $\mathrm{Fe}^{2+}$ e $\mathrm{F}^{3+}$ na solução 1; Em (3) adição de $\mathrm{NaOH}$ completando o processo de formação da magnetita $\left(\mathrm{Fe}_{3} \mathrm{O}_{4}\right)$. 
Posteriormente a este procedimento, o precipitado formado foi coletado em tubos falcon, lavado com água ultrapura e centrifugado por 10 vezes. Logo a seguir, os tubos com os precipitados foram secos em estufa por volta de $60{ }^{\circ} \mathrm{C}$. Após este procedimento, obteve-se um material magnético escuro de coloração negra conforme apresentado na figura 4. A figura 3 resume as etapas de síntese descritas para a preparação das duas amostras de carvão magnético (CAMG A e CAMG B) utilizadas neste trabalho. Estes foram elaborados a partir de carvões ativados diferentes, carvão A (produzido pela Synth®) e carvão B (produzido pela Sigma Aldrich®) respectivamente, com o intuito de verificar a influência do tipo de carvão utilizado na elaboração do carvão magnético, visando a adsorção de BPA das amostras contaminadas.
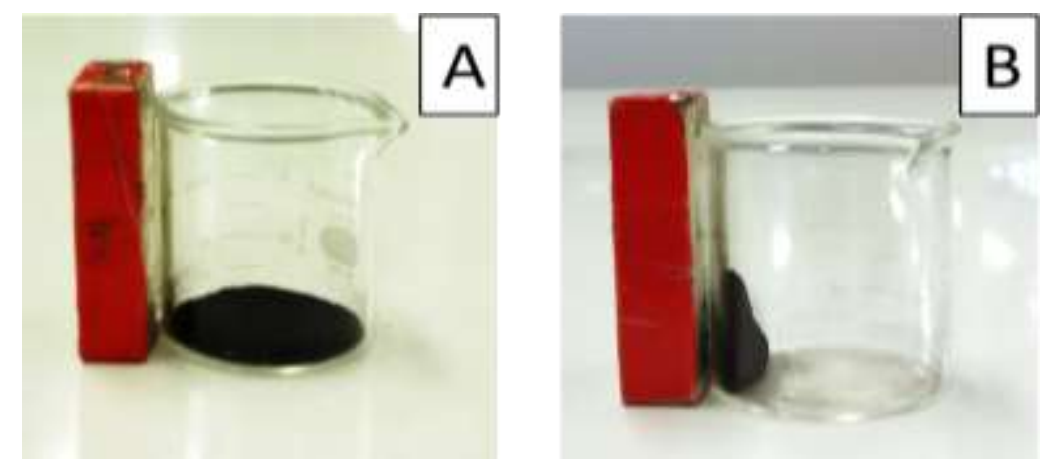

Figura 4 - Imagem do carvão ativado sem o $\mathrm{Fe}_{3} \mathrm{O}_{4}$ impregnado (4-A) e carvão magnético CAMG (4-B) produzido após a preparação

\subsubsection{Caracterização}

\subsubsection{Instrumentação}

A caracterização das amostras de carvões magnéticos preparados foi realizada pelas técnicas de difração de raios $\mathrm{X}$ (DRX), microscopia eletrônica de varredura (MEV), dosagem de ferro por ICP-OES (espectrometria de emissão atômica com 
plasma indutivamente acoplado), medidas de magnetização à temperatura ambiente (MAG), medidas de área superficial específica por Brunauer-Emmett-Teller (BET). A espectroscopia UV-Vis foi utilizada para verificar e quantificar a adsorção de BPA pelo carvão magnético, sendo possível a elaboração das isotermas através desta técnica. O quadro abaixo relaciona, de forma simplificada, as principais técnicas utilizadas e as informações delas obtidas.

\begin{tabular}{|c|c|}
\hline TÉCNICA & FINALIDADE \\
\hline DRX & $\begin{array}{l}\text { Evidenciar, qualitativamente, a presença amorfa do carvão e investigar a } \\
\text { fase cristalina das nanopartículas magnéticas assim como o diâmetro dos } \\
\text { cristalitos. }\end{array}$ \\
\hline MEV & $\begin{array}{l}\text { Averiguar a morfologia e a interação física entre nanopartículas } \\
\text { magnéticas e o carvão. }\end{array}$ \\
\hline ICP-OES & $\begin{array}{l}\text { Determinar o teor de nanopartículas magnéticas no compósito para } \\
\text { correlacioná-lo com os resultados de medidas de magnetização. }\end{array}$ \\
\hline MAG & $\begin{array}{l}\text { Investigar as diferenças de características de magnetização de cada } \\
\text { material adsorvente, bem como o teor de material magnético nessas } \\
\text { amostras. }\end{array}$ \\
\hline BET & $\begin{array}{l}\text { Obter os parâmetros de área superficial específica dos carvões ativados } \\
\text { e dos carvões magnéticos. }\end{array}$ \\
\hline UV-Vis & $\begin{array}{l}\text { Quantificar a adsorção de BPA pelos carvões magnéticos para respectiva } \\
\text { elaboração de isotermas. }\end{array}$ \\
\hline
\end{tabular}

Tabela 2 - Técnicas utilizadas para caracterização e análises de adsorção. 3.1.2.2 Determinação da estrutura cristalina por difração de raios $X$ - DRX 
A técnica de difração de raios $X$ foi utilizada para verificar qualitativamente a presença de estruturas de magnetita sobre a superfície amorfa do carvão, além de determinar características como a simetria cristalina, parâmetros de rede, distâncias interplanares, defeitos estruturais, entre outros. A técnica utiliza o comprimento de onda da mesma ordem de grandeza que a distância entre os átomos. Desta forma, a relação entre o ângulo de difração medido $(\theta)$, o comprimento de onda utilizado $(\lambda)$ e as distâncias interplanares (dhkl) da estrutura cristalina é dada pela Lei de Bragg $n \lambda=$ $2 d x_{h k l} \operatorname{sen} \theta$, onde $\mathrm{n}$ corresponde a ordem de interferência. Com os valores das distâncias interplanares calculados e com as respectivas intensidades relativas, estes valores foram comparados aos de tabelas ASTM (American Society for Testing Materials). Dessa maneira, se conseguiu indexar os picos característicos associados às famílias de planos reticulares (hkl) da estrutura cristalina. Após indexar o difratograma, determinou-se o parâmetro de malha cúbico (a) que é comparado com o valor de referência das fichas ASTM para confirmar a estrutura cristralina obtida no processo de síntese $^{48}$. A análise foi realizada num difratômetro de raios $\mathrm{X}$ de marca Rigaku, modelo Miniflex 600. Antes da análise, as amostras foram secas em estufa numa temperatura a $60^{\circ} \mathrm{C}$, pulverizadas num graal de ágata e prensadas em um porta amostras de vidro.

\subsubsection{Estudo da morfologia e textura por microscopia eletrônica de varredura - MEV}

A microscopia eletrônica de varredura foi utilizada para averiguar a morfologia do sistema elaborado entre o carvão e as nanopartículas magnéticas, além de verificar a disposição de magnetita impregnada no carvão ativado suporte. A técnica se baseia no uso de um feixe de elétrons no lugar de fótons utilizados em um microscópio óptico 
convencional, o que permite solucionar o problema de resolução em relação à microscopia ótica comum. Para a realização da análise, as amostras de carvão ativado puro e de carvões magnéticos foram pulverizadas e trituradas com o auxílio de um graal de ágata e, posteriormente, secas em estufa a $60^{\circ} \mathrm{C}$ por $24 \mathrm{~h}$. Após este procedimento, as amostras foram colocadas em fitas de carbono dupla face sobre suportes de alumínio (stubs) utilizados nas análises de MEV. Posteriormente, as amostras colocadas nestes suportes foram metalizadas. Após a metalização, as amostras foram analisadas no microscópio eletrônico de marca FEI Company®, modelo Quanta FEG 250, utilizando uma tensão de 7,5 kV, spot size 3,5 e detector de elétrons espalhados (Back Scattering). Imagens em diferentes ampliações foram obtidas para respectiva comparação com parâmetros de magnetização e de teor de ferro impregnado.

\subsubsection{Determinação do teor de ferro por espectrometria de emissão atômica com plasma indutivamente acoplado (ICP-OES)}

A determinação do teor de ferro por ICP objetiva verificar a quantidade de nanopartícula de magnetita que foi depositada na superfície do carvão ativado, foi realizada por ICP-OES (Espectrometria de emissão atômica com plasma indutivamente acoplado) num espectrômetro PerkinElmer, modelo Optima 8000, com potência do plasma $400 \mathrm{~W}$, vazão do gás do plasma $10 \mathrm{~L} / \mathrm{min}$, vazão do gás auxiliar 0,2 L/min, nebulização $0,7 \mathrm{~L} / \mathrm{min}$, purga da óptica $5 \mathrm{~mL} / \mathrm{min}$ (nitrogênio), injetor Alumina ( $2 \mathrm{~mm}$ d.i.), Câmara de nebulização Scott, com processamento do sinal área sob o pico, tempo de integração automático, vazão de introdução da amostra $1,5 \mathrm{~mL} / \mathrm{min}$ e 2 replicatas. No preparo das amostras, $10 \mathrm{~g}$ de CAMG A foram digeridos num balão volumétrico de $10 \mathrm{~mL}$ com ácido clorídrico $(\mathrm{HCl})$ concentrado. A amostra de CAMG B foi preparada 
de forma semelhante, digerindo $25 \mathrm{mg}$ de nanopartícula com $\mathrm{HCl}$ concentrado em um balão volumétrico de $25 \mathrm{~mL}$. Tanto para o CAMG A quanto para o CAMG B as soluções preparadas produziram uma solução na proporção de 1:1 (m/V). As duas soluções sofreram diluições para a execução da análise no ICP-OES nos quais os resultados serão apresentados na etapa de caracterização.

\subsubsection{Magnetização por magnetometria de amostra vibrante - VSM}

A Magnetometria de Amostra Vibrante, ou VSM (Vibrating Sample Magnetometer) foi desenvolvida por Foner em 1955 e é atualmente uma das técnicas mais utilizadas, não só por ser relativamente sensível (sensibilidade da ordem de $10^{-5}$ emu), mas também por seu funcionamento simples e baixo custo de manutenção. A técnica fornece informações sobre as propriedades magnéticas da amostra por meio da curva de histerese, e se baseia na obtenção de magnetização por indução ${ }^{49} \mathrm{O}$ VSM consiste em uma haste rígida fixa a um vibrador. A amostra deve ser colocada na outra extremidade da haste e posicionada entre dois eletroímãs e um conjunto de bobinas detectoras. Para se obter o sinal da magnetização, faz-se vibrar a amostra perpendicularmente ao campo aplicado que, ao oscilar, produz uma variação do fluxo de campo magnético local, gerando uma corrente induzida alternada nas bobinas detectoras posicionadas em torno da amostra. Desta forma é registrada a intensidade do momento magnético da amostra. Os pós magnéticos das amostras, obtidos por lavagem com água ultrapura e secagem em estufa, foram analisados em magnetômetro VSM, em uma faixa de campo magnético, de $-18 \mathrm{kOe}$ a $+18 \mathrm{kOe}$, a $25^{\circ} \mathrm{C}$. O objetivo desta técnica foi verificar se havia diferenças magnéticas entre os dois carvões magnéticos e o teor de $\mathrm{Fe}_{3} \mathrm{O}_{4}$ no material magnético elaborado. 


\subsubsection{Análise porosimétrica e da área superficial por BET - Brunauer-Emmett-}

Teller

A determinação da área superficial e distribuição do volume dos poros dos carvões ativados e dos carvões magnéticos, isotermas de adsorção e dessorção de $\mathrm{N}_{2}$ foram realizadas a $77 \mathrm{~K}$, em um equipamento de marca Micromeritics, modelo AS AP 2020 V3.02 G, com os seguintes parâmetrospara análise: massa da amostra por volta de $0,20 \mathrm{~g}$,

free space quente próximo de $16,0 \mathrm{~cm}^{3}$, free space frio por volta de $48,0 \mathrm{~cm}^{3}$, intervalo de equlíbrio de $10 \mathrm{~s}$, nenhuma dose de baixa pressão, desgasificação automática. As amostras foram trituradas em um graal de ágata, secas em estufa a $60{ }^{\circ} \mathrm{C}$ e posteriomente colocadas em um dessecador.

\subsection{Estudos para avaliação de remoção de BPA}

\subsubsection{Metodologia para determinação de BPA em amostras aquosas}

Conforme M. del Olmo et al..$^{50}$, o BPA apresenta frequência de excitação entre os comprimentos de onda na faixa de 225 e $278 \mathrm{~nm}$. Nestes comprimentos de onda, torna-se possível a análise especfotométrica dos padrões utilizados. Por se tratar de um material hidrofóbico (solubilidade entre 120 a $300 \mathrm{mg} / \mathrm{L}$ ), o BPA é mais solúvel em álcool do que em água. Desta forma, existe a necessidade de solubilizá-lo em álcool ou em soluções aquo-etanólicas antes de preparar a solução aquosa. Para o preparo da solução aquosa, 25,0 mg de BPA foram primeiramente solubilizados em $5 \mathrm{~mL}$ de álcool absoluto (99,8\%). Em seguida, essa solução foi misturada com $50 \mathrm{~mL}$ de água ultrapura. 
O álcool foi posteriormente evaporado a uma temperatura que varia entre 75 a $80^{\circ} \mathrm{C}$ numa chapa de aquecimento. A solução foi então completada num balão volumétrico de $250 \mathrm{~mL}$ produzindo uma solução de trabalho de 100,0 mg/L. Cabe considerar que, apesar esta solução padrão não se encontrar totalmente livre de álcool (por se tratar de uma solução azeotrópica - mistura de líquidos composta por dois ou mais componentes que, em proporções específicas dos constituintes, formam uma mistura com ponto de ebulição constante e fixo ${ }^{51}$ ), considerou-se a quantidade de álcool residual como desprezível. A figura 5 resume o processo descrito acima de preparação da solução padrão de BPA.

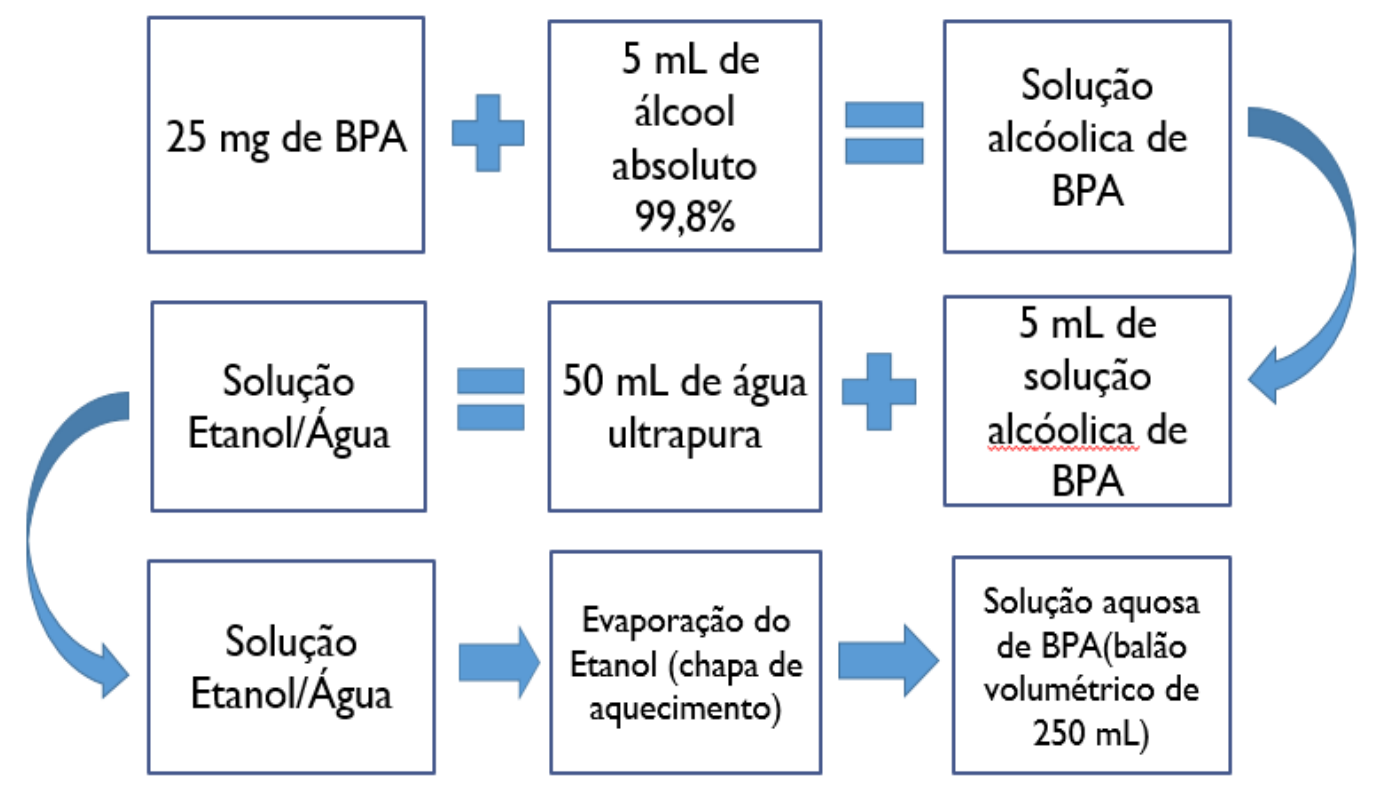

Figura 5 - Representação esquemática do preparo da solução padrão $100 \mathrm{mg} / \mathrm{L}$ de BPA.

Após o preparo desta solução de trabalho, foram feitos 10 padrões de 0,$5 ; 1,0$; 2,5; 5,$0 ; 7,5 ; 10,0 ; 20,0 ; 30,0 ; 40,0$ e 50,0 mg/L que foram usados para elaboração da calibração do experimento. O equipamento utilizado foi um espectrofotômetro UV-VIS Hitachi, modelo 3900H. Os parâmetros para análise foram os seguintes: a varredura feita numa faixa entre 200 e $350 \mathrm{~nm}$, numa velocidade de escaneamento de 1200 $\mathrm{nm} / \mathrm{min}$, iniciando o zero a partir de $325 \mathrm{~nm}$. As medidas foram feitas na região do 
ultravioleta utilizando unicamente a lâmpada de deutério, com $2 \mathrm{~nm}$ de abertura da fenda. O experimento utilizou a absorsão máxima em $277 \mathrm{~nm}$ para calibrabração dos padrões de BPA.

\subsection{Estudo de remoção de BPA}

Para avaliar a remoção de BPA das amostras aquosas, foram feitas isotermas de adsorção variando a massa de carvão adsorvente e também o tempo de contato (cinética de adsorção) entre as soluções e o carvão magnético, juntamente com o estudo de eficiência de remoção de BPA das soluções aquosas usando o CAMG. Além disso, também foi avaliada a influência do pH na adsorção de BPA destas amostras.
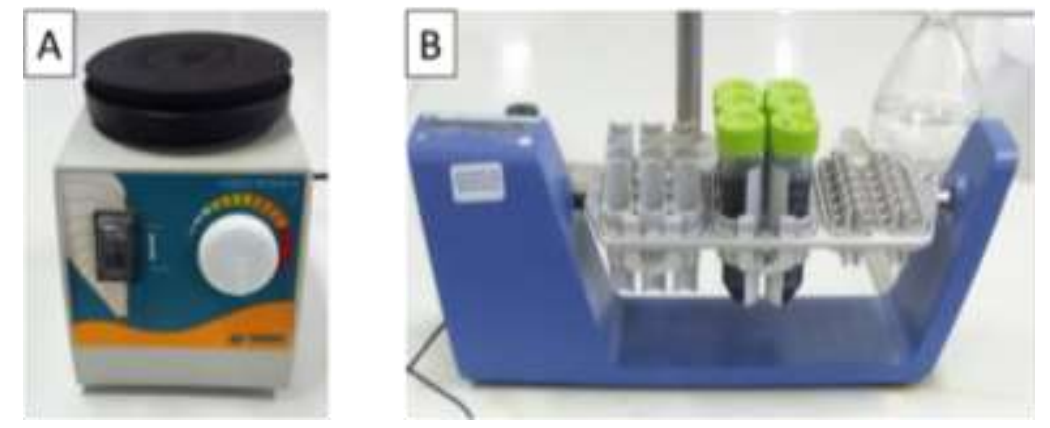

Figura 6 - Tipos de agitações utilizadas: agitação por vórtex (6-A) e agitação por tombamento (6-B).

Estes estudos foram realizados utilizando duas agitações (vórtex e tombamento), visando averiguar qual delas seria mais eficiente na remoção de BPA das amostras contaminadas. Nas figuras 6-A e 6-B, são mostrados os equipamentos utilizados para realizar estes dois tipos de agitações.

Para a elaboração das isotermas e o estudo de eficiência de adsorção, massas de CAMG variando numa faixa de 2 a $50 \mathrm{mg}$ de CAMG foram adicionadas em tubos falcon com a mesma concentração de BPA $(20$ mg/L na agitação vortex e 40 mg/L no 
tombamento) a um volume de $40 \mathrm{~mL}$ para cada solução nos tubos. Primeiramente, retirou-se uma alíquota de $2 \mathrm{~mL}$ de cada amostra de solução com BPA para realização das medidas de absorbâncias no UV-VIS sem o CAMG. Após este procedimento, as quantidades de massas já citadas foram adicionadas a estas soluções.

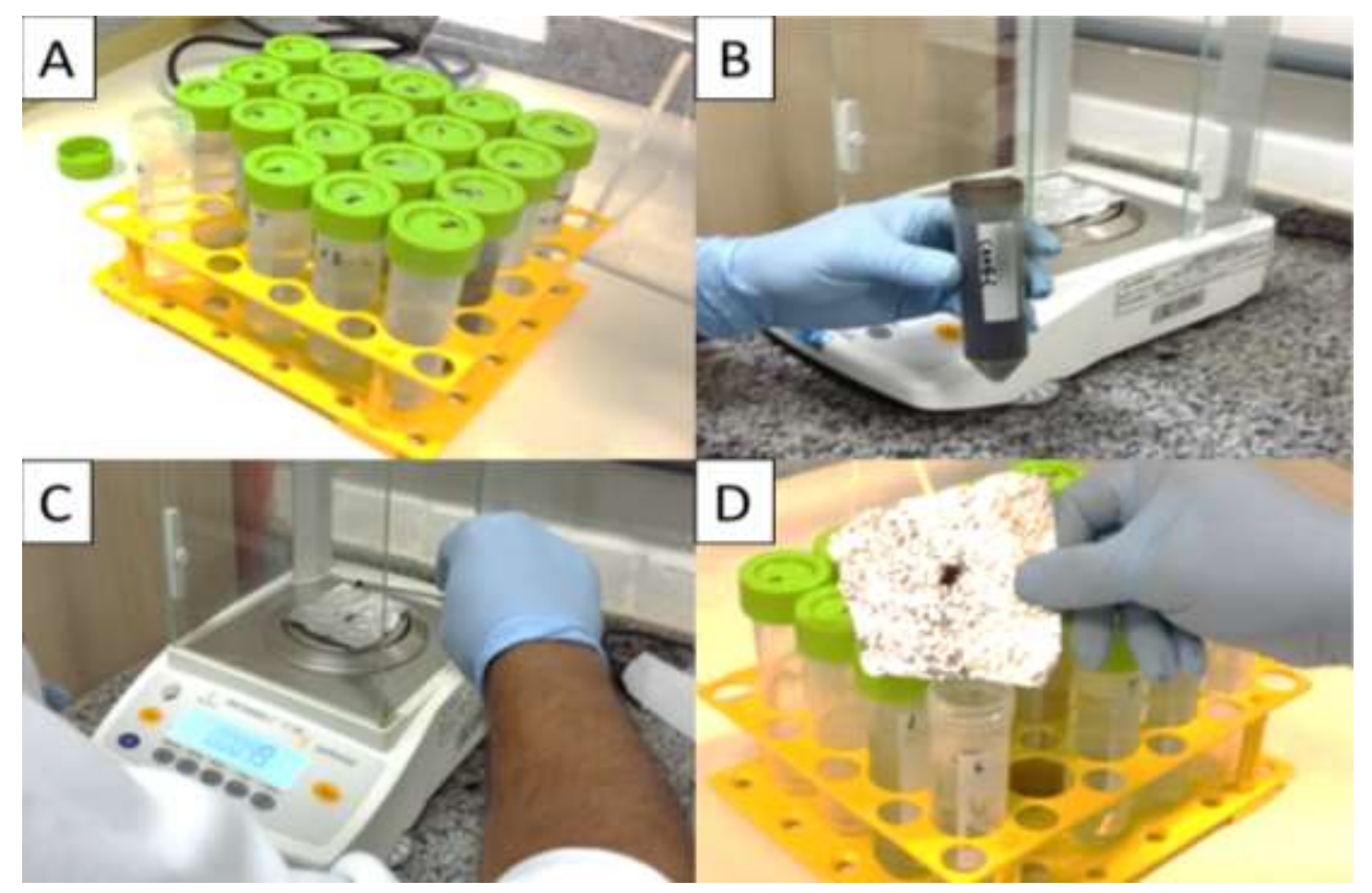

Figura 7 - Foto da adição de partículas para realização do estudo de adsorção. Figura 7-A: imagem das amostras contaminadas com BPA em tubos falcon; Figura 7-B: amostra de carvão magnético (CAMG A) dentro de um tubo falcon. Figura 7-C: pesagem de pequenas quantidades de massa de CAMG A. Figura 7-D: adição de CAMG A para realização do estudo de eficiência de remoção nas amostras contaminadas.

Após uma interação de 2 horas entre a amostra com BPA poluente e a partícula, as absorbâncias foram medidas novamente no UV-VIS com a intenção de verificar a taxa de remoção de BPA por massa de carvão magnético. Este procedimento foi repetido nos dois métodos de agitação vórtex e tombamento, e também tanto para o CAMG A quanto para o CAMG B visando a respectiva elaboração dos gráficos de isotermas de adsorção e de eficiência de remoção. A figura 7 ilustra como foi feito o processo de adição do carvão magnético às soluções contaminadas com BPA. 


\subsubsection{Estudo Cinético (tempo de contato)}

Neste estudo, avaliou-se a cinética de adsorção do CAMG para o BPA. Utilizouse um tubo falcon com uma solução $20 \mathrm{mg} / \mathrm{L}$ (para o vórtex) ou $40 \mathrm{mg} / \mathrm{L}$ (para o tombamento) de BPA. Inicialmente, pipetou-se uma alíquota de $2 \mathrm{~mL}$ da solução e foi feita uma primeira medida no UV-VIS sem a adição de CAMG. Posteriormente, foram adicionados $5 \mathrm{mg}$ (na agitação vórtex) ou $20 \mathrm{mg}$ (no tombamento) de CAMG na solução. A cada intervalo de 5 minutos, após agitação, em vórtex ou tombamento, foram retiradas alíquotas de $2 \mathrm{ml}$ e medidas novamente no UV-VIS. Os dados obtidos foram utilizados para a elaboração de curvas cinéticas de adsorção. O estudo cinético foi feito tanto com o CAMG A quanto com o CAMG B.

\subsubsection{Estudo de influência do pH}

Este estudo foi realizado de forma semelhante ao estudo de isotermas. De início, 9 tubos falcon contendo uma solução de BPA de mesma concentração $(20 \mathrm{mg} / \mathrm{L}$ no vortex e $40 \mathrm{mg} / \mathrm{L}$ em tombamento) foram calibradas em diferentes pHs: 2, 4, 6, 7, 8, 9, 10, 11 e 12. Posteriormente, retirou-se uma alíquota de $2 \mathrm{~mL}$ de cada uma delas e leituras no UV-VIS foram realizadas nos diferentes pHs. Após este procedimento, foram adicionados $5 \mathrm{mg}$ (vótex) ou $20 \mathrm{mg}$ (tombamento) de CAMG em cada tudo. Após uma interação de 2 horas entre as soluções e a nanopartícula, foram retiradas novamente alíquotas de $2 \mathrm{~mL}$ e leituras de UV-VIS foram feitas para cada tudo. O objetivo foi avaliar o melhor pH para a realização das medidas e também a influência do mesmo na adsorção de BP pelas partículas. Este procedimento foi realizado tanto com o CAMG A quanto com o CAMG B. 


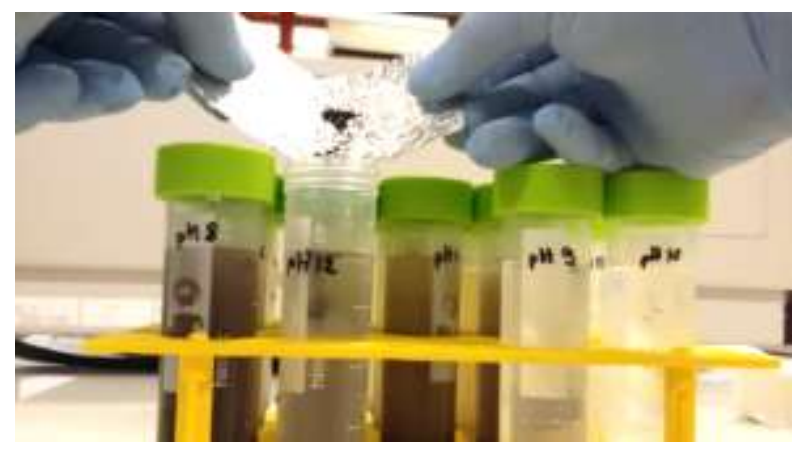

Figura 8 - Foto da adição de partícula nas soluções com BPA para o teste de pH.

\section{RESULTADOS E DISCUSSÕES}

\section{1 Caracterização do Carvão Magnético (CAMG)}

A seguir serão apresentados os resultados das análises de caracterização das amostras de carvão e carvão magnético por: difração de raios $\mathrm{X}$, dosagem de $\mathrm{Fe}_{3} \mathrm{O}_{4}$ por ICP-OES, morfologia por microscopia eletrônica de varredura - MEV , magnetização por magnetometria de amostra vibrante - VSM, área superficial específica por BET (Brunauer-Emmett-Teller).

\subsubsection{Determinação da estrutura cristalina por difração de raios X (DRX)}

Para a caracterização do diâmetro dos cristalinos e do teor de ferro dos carvões magnéticos foi utilizada a técnica de difração de raios $X$ (DRX). Na figura 9, são apresentados os difratogramas de raios $\mathrm{X}$ de cada amostra de carvão ativado e magnético. 


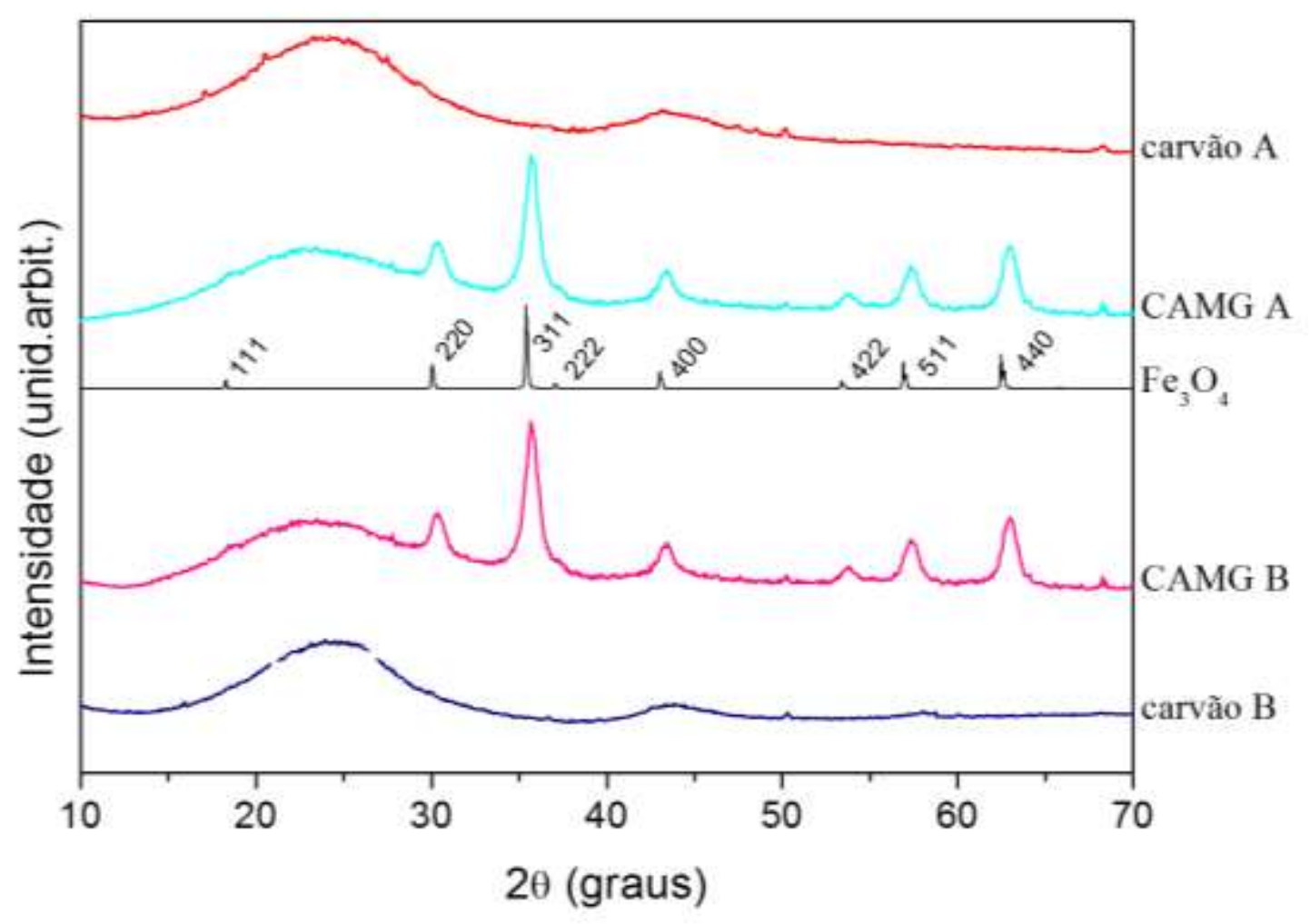

Figura 9 - Difratograma dos carvões ativados A e B e, dos carvões magnéticos CAMG 2 e CAMG 3.

O caráter nanoparticulado do óxido de ferro magnético é demonstrado pela presença do pico de difração (311 presente na magnetita) encontrado na mesma posição nos difratogramas do CAMG A e CAMG B, indicando que ocorreu a impregnação de $\mathrm{Fe}_{3} \mathrm{O}_{4}$ sobre as formas amorfas dos carvão A e do carvão B. O diâmetros cristalinos, calculados a partir do pico principal de difração (311), foram 9,7 nm e 10,2 nm, para as nanopartículas de magnetita incorporadas ao CAMG A e CAMG B, respectivamente. A microscopia de varredura permite uma visualização melhor da morfologia e interação física entre essas duas fases. 


\subsubsection{Dosagem de $\mathrm{Fe}_{3} \mathrm{O}_{4}$ por ICP-OES}

A tabela 3 mostra o teor percentual em massa de $\mathrm{Fe}_{3} \mathrm{O}_{4}$ obtido para cada tipo de carvão magnético (CAMG A e CAMG B) elaborado. Os dados demonstraram que, com o mesmo tipo de preparo, foi identificada uma menor quantidade de magnetita impregnada no CAMG A $(29,63 \%)$ que no CAMG B $(36,48 \%)$. Estes fatores podem influenciar tanto na quantidade de BPA adsorvido quanto nos aspectos de magnetização em cada carvão magnético elaborado. Isto porque um teor maior de magnetita poderia reduzir a quantidade de poros no carvão que estariam aptos para adsorver o BPA, diminuindo, dessa forma, a capacidade de adsorção do mesmo. Além disso, uma maior dosagem de magnetita impregnada poderia aumentar os atributos magnéticos do carvão magnético preparado.

\begin{tabular}{|cc|}
\hline Amostra (NP) & $\begin{array}{c}\mathrm{Fe}_{3} \mathrm{O}_{4} \\
\%(\mathrm{~m} / \mathrm{m})\end{array}$ \\
\hline CAMG A & 29,63 \\
\hline \hline CAMG B & 36,48 \\
\hline
\end{tabular}

Tabela 3: Resultado da análise de teor de $\mathrm{Fe}_{3} \mathrm{O}_{4}$ por ICP - OES.

Este resultado será comparado com dados posteriores obtidos nas análises de MEV, magnetização (MAG), BET, eficiência de remoção e isotermas de adsorção.

\subsubsection{Determinação da morfologia e textura por Microscopia Eletrônica de Varredura (MEV)}


As figuras 10 e 11 apresentam a morfologia dos dois carvões ativados (carvão A e carvão B) utilizados na elaboração, além das imagens dos carvões magnéticos (CAMG A e CAMG B) produzidos com cada espécie de carvão (A e B).

As imagens foram feitas em diferentes magnitudes para um mesmo ponto de observação dos carvões. As figuras 10-A, 10-B e 10-C mostram o Carvão A em ampliações de 5.000, 30.000 e 100.000 vezes respectivamente. Na figura 10-B, os poros do carvão começam a aparecer na imagem e em 10-C, estão totalmente em evidência. Da mesma forma acontece com o Carvão B nas figuras 10-D, 10-E e 10-F, com o aumento da magnitude de 5.000 para 30.000 e 100.000 vezes, respectivamente. Na figura 10-D, foi capturada a imagem de um fragmento do carvão $\mathrm{B}$, que vai sofrendo ampliações nas figuras 10-E e 10-F. Na figura 10-E, os poros do carvão B não parecem tão evidentes, enquanto que em 10-F, podem ser notados com maior facilidade. De acordo com o observado nestas figuras, os poros do carvão A parecem maiores do que aqueles da superfície do carvão B. Estes fatores podem influenciar na quantidade de magnetita $\left(\mathrm{Fe}_{3} \mathrm{O}_{4}\right)$ impregnada na superfície do carvão quanto nas características de adsorção do carvão magnético produzido.

Já nas figuras 11-A, 11-B e 11-C são apresentadas imagens do carvão magnético produzido com o Carvão A (CAMG A) nas magnitudes de 30.000, 100.000 e 200.000 vezes respectivamente. Nas figuras 11-B e 11-C nota-se o aparecimento de pontos brancos podendo se tratar da magnetita impregnada dispersa sobre a superfície do carvão, demonstrando que o $\mathrm{Fe}_{3} \mathrm{O}_{4}$ se encontra sobre a superfície do carvão magnético. Nas figuras 11-D, 11-E e 11-F encontramos o carvão magnético produzido com o Carvão B (CAMG B) nas ampliações de 30.000, 100.000 e 200.000 vezes respectivamente. Na figura 11-D, é mostrado um fragmento do CAMG B, e nas figuras 11-E e 11-F é apresentado como a magnetita se encontra espalhada na superfície do 
carvão magnético. Da mesma forma que no CAMG A, a magnetita se encontra dispersa sobre a superfície do CAMG B, contudo, de uma forma menos evidente que no CAMG A.

A grosso modo, sugere-se que a maior parte da magnetita impregnada no CAMG B encontra-se obstruindo os poros do mesmo, motivo pelo qual, pode ser observado uma diminuição na quantidade de poros na superfície do CAMG B.

Os aspectos aqui mencionados podem influenciar tanto na questão das características de adsorção do poluente (BPA) quanto no magnetismo do material adsorvente. 

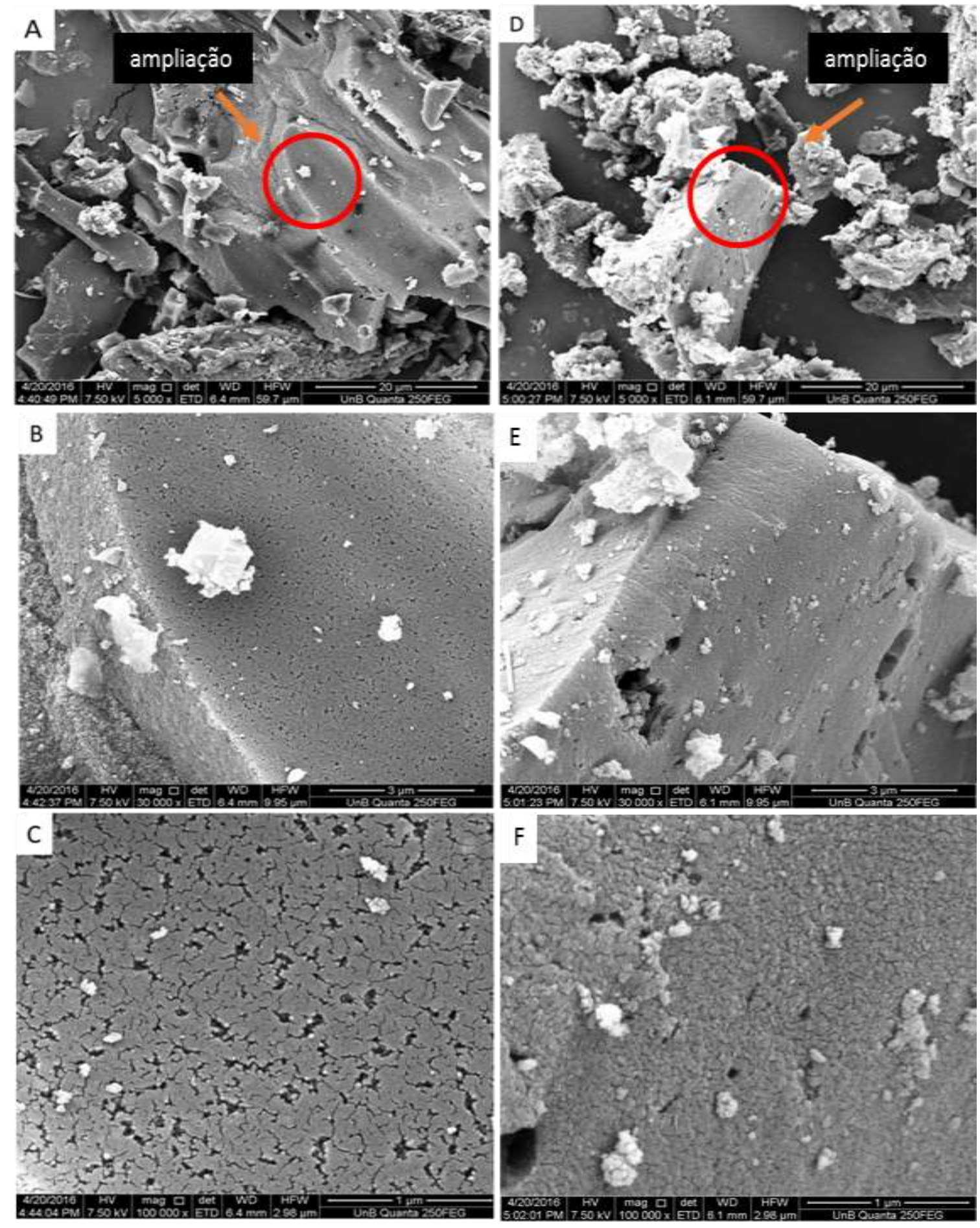

Figura 10 - imagens de microscopia eletrônica de varredura - MEV. Em 10-A, 10-B e 10-C, são apresentadas as micrografias do carvão A nas ampliações de 5.000. 30.000 e 100.000 vezes, respectivamente. Em 10-D, 10-E e 10-F, são mostradas as micrografias do carvão $B$ nas ampliações de 5.000, 30.000 e 100.000 vezes, respectivamente. 

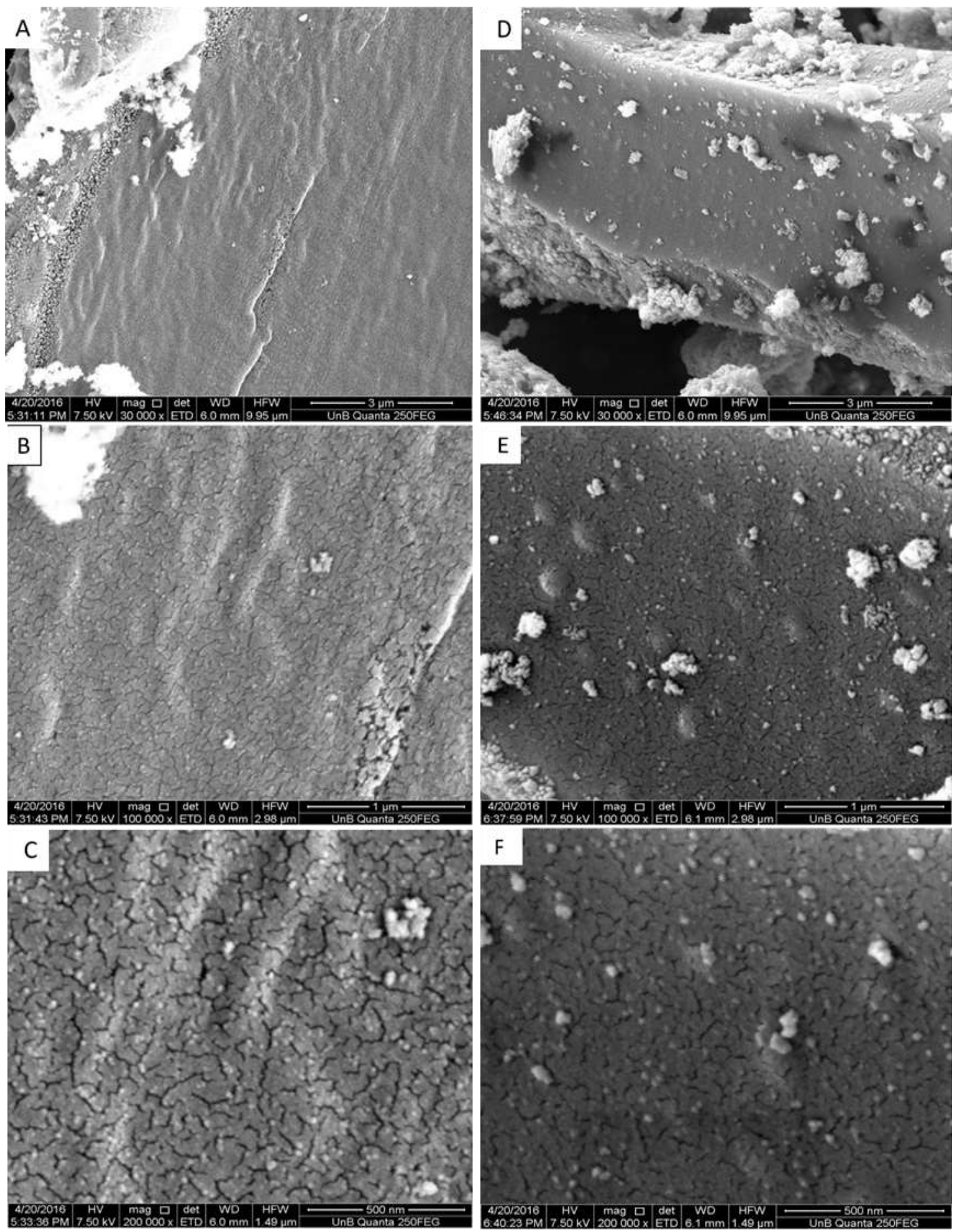

Figura 11 - imagens de microscopia eletrônica de varredura - MEV. Nas imagens 11-A, 11-B e 11-C, são apresentadas as micrografias do CAMG A nas magnitudes de 30.000, 100.000 e 200.000 vezes, respectivamente. $E$ nas imagens 11-D, 11-E e 11-F, são mostradas as micrografias do CAMG B nas magnitudes de 30.000, 100.000 e 200.000 vezes, respectivamente. 


\subsubsection{Magnetização por magnetometria de amostra vibrante - VSM}

Para avaliar as propriedades magnéticas das amostras de carvão magnéticos, medidas de magnetização foram efetuadas, a temperatura ambiente, em um ciclo de histerese, para um campo magnético aplicado de -17 kOe a 17 kOe. Dessa maneira, a figura 12 mostra as curvas de magnetização (M), à temperatura ambiente, em função do campo magnético aplicado (H) para CAMG A e CAMG B. É possível observar que a magnetização aumenta à medida que o campo magnético se intensifica, até atingir magnetização de saturação em cerca de 23,5 emu/g para ambas as amostras. Além disso, quando o campo é diminuído e invertido para fechar o ciclo de histerese, é possível notar que não há magnetização remanescente e nem campo coercitivo, indicando que as partículas apresentam características superparamagnéticas. Como a contrapartida do carvão ativo apresenta magnetização praticamente nula em relação às nanopartículas de magnetita que formam o carvão magnético, que têm valor típico de magnetização de $80 \mathrm{emu} / \mathrm{g}$, se assume que a origem da magnetização do carvão magnético é puramente devida à parecença das nanopartículas de óxido de ferro. Além disso, ao normalizar a curva de magnetização pela magnetização da $\mathrm{Fe}_{3} \mathrm{O}_{4}$ pura, estima-se um percentual em massa de material magnético de cerca de 30\%, valor em bom acordo com aqueles determinados por dosagem química. 


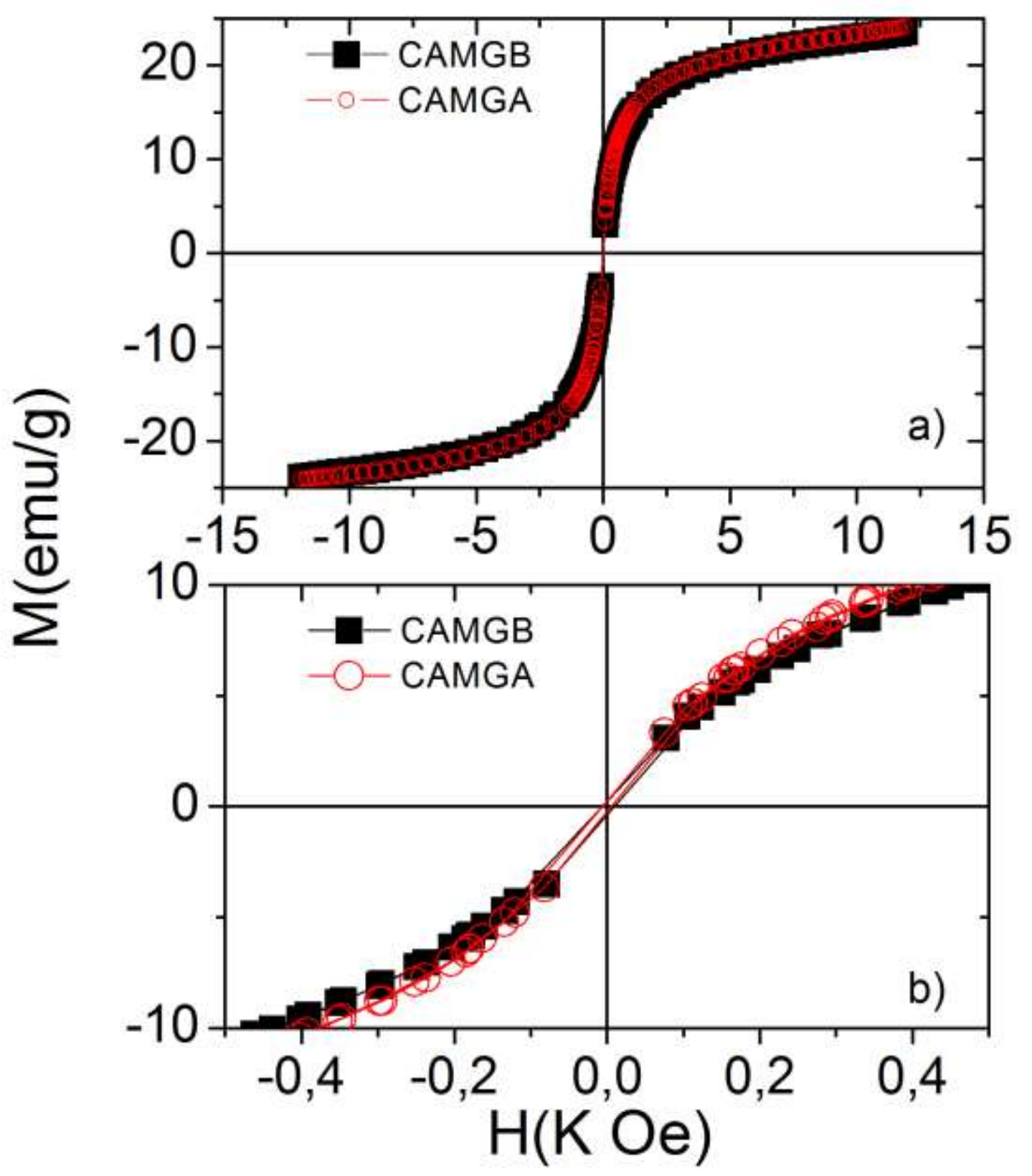

Figura 12 - A) Curva de magnetização versus campo magnético aplicado para as amostras de CAMG A e CAMG B) O gráfico em detalhe mostra a histerese a baixo campo. 


\subsubsection{Análise porosimétrica e área superficial por BET - Brunauer-Emmett-}

Teller

$\mathrm{Na}$ determinação da área superficial específica utilizando BET, identificou-se uma redução da área superficial entre o carvão suporte e carvão magnético após impregnação da magnetita. O carvão $A$, antes da elaboração do carvão magnético, apresentou uma área superficial de $736,5 \mathrm{~m}^{2} / \mathrm{g}$, enquanto que o CAMG A, elaborado com o este mesmo carvão, apresentou área superficial de $437,15 \mathrm{~m}^{2} / \mathrm{g}$. O mesmo aconteceu com o carvão B que apresentou uma área de 855,36 m²/g, reduzindo esta área para 320,39 m²/g após a elaboração do CAMG B. A redução do valor da área superficial do CAMG B em relação ao CAMG A confirma uma maior impregnação de magnetita sobre o carvão B do que sobre o carvão A, fato já observado na dosagem de óxido de ferro medida por ICP-OES. Nas figuras 13 e 14, são apresentadas as curvas de isotermas lineares de adsorção/dessorção dos carvões A e B e do CAMG A e CAMG B.

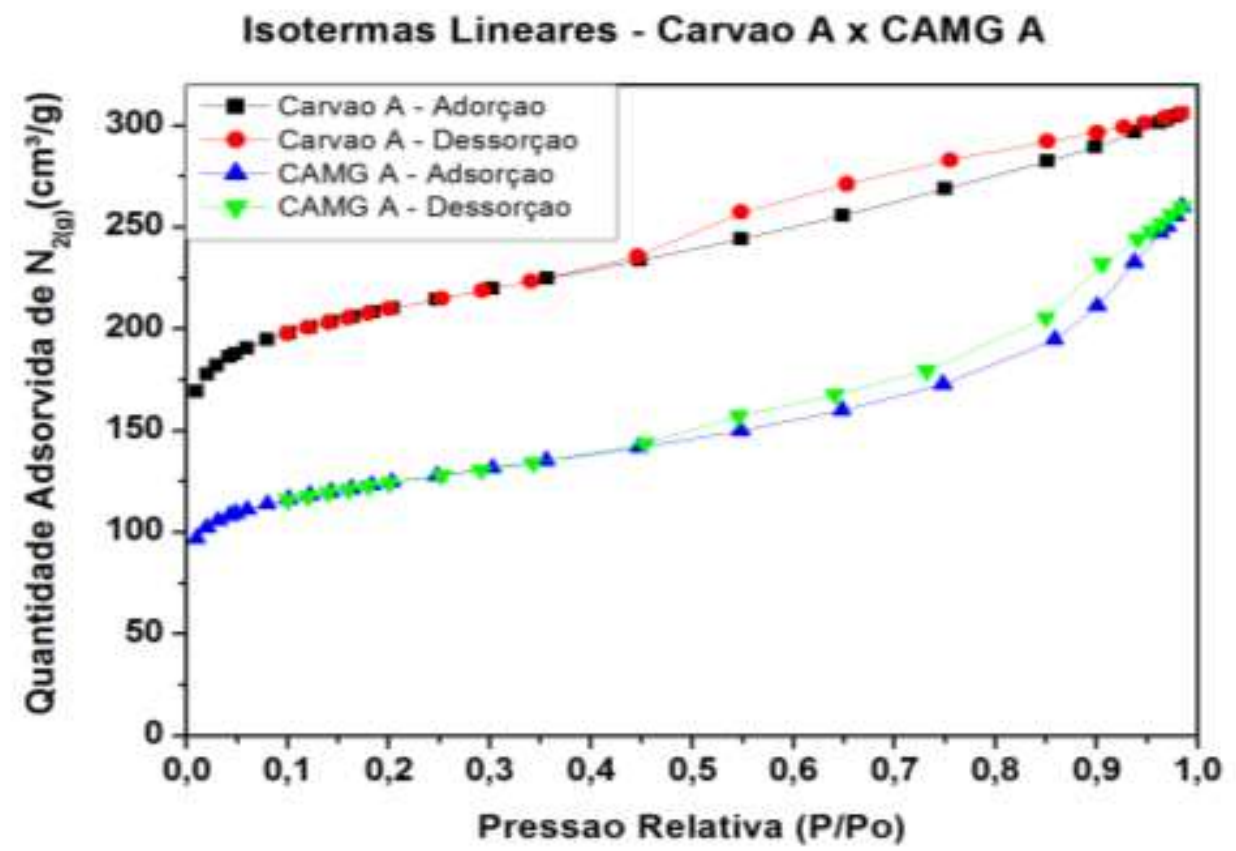

Figura 13 - Gráfico de isotermas de adsorção/dessorção de $\mathrm{N}_{2}$ para 0 carvão $A$ e 0 CAMG A. 


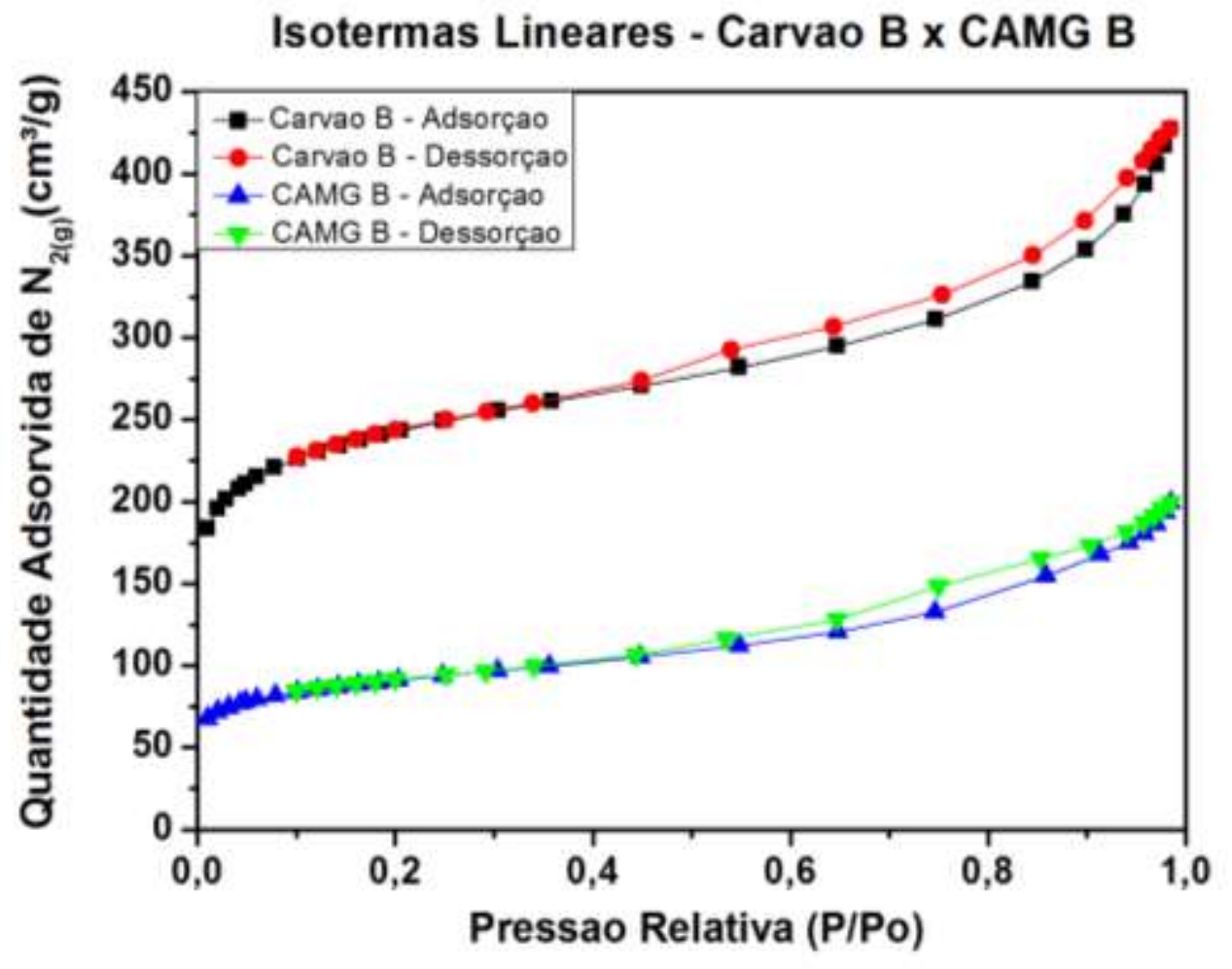

Figura 14 - Gráfico de Isotermas de adsorção/dessorção de $\mathbf{N}_{2}$ para 0 carvão $B$ e o CAMG B.

Na figura 15 e 16, são apresentadas as distribuições de poro por volume de cada carvão A e B, e dos carvões magnéticos CAMG A e CAMG B.

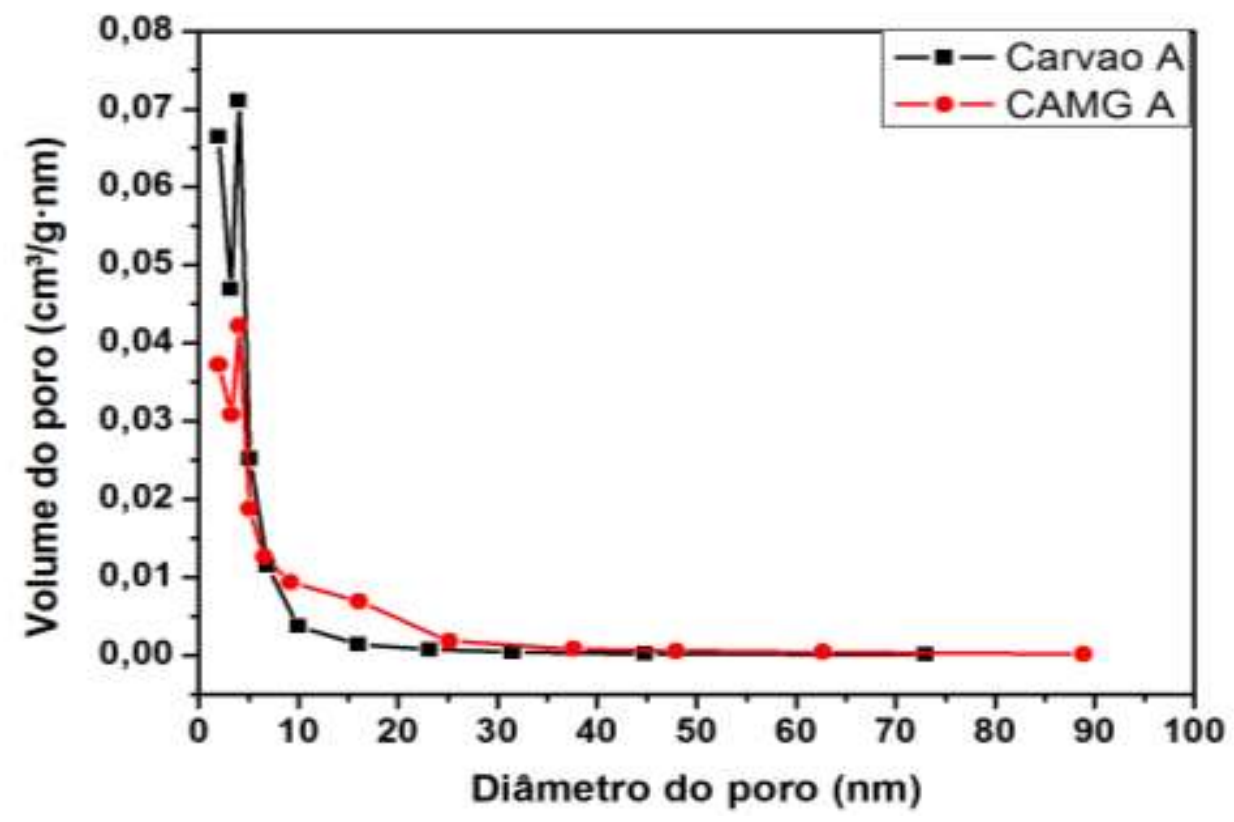

Figura 15 - Distribuição de poro por volume - Carvão A e CAMG A. 


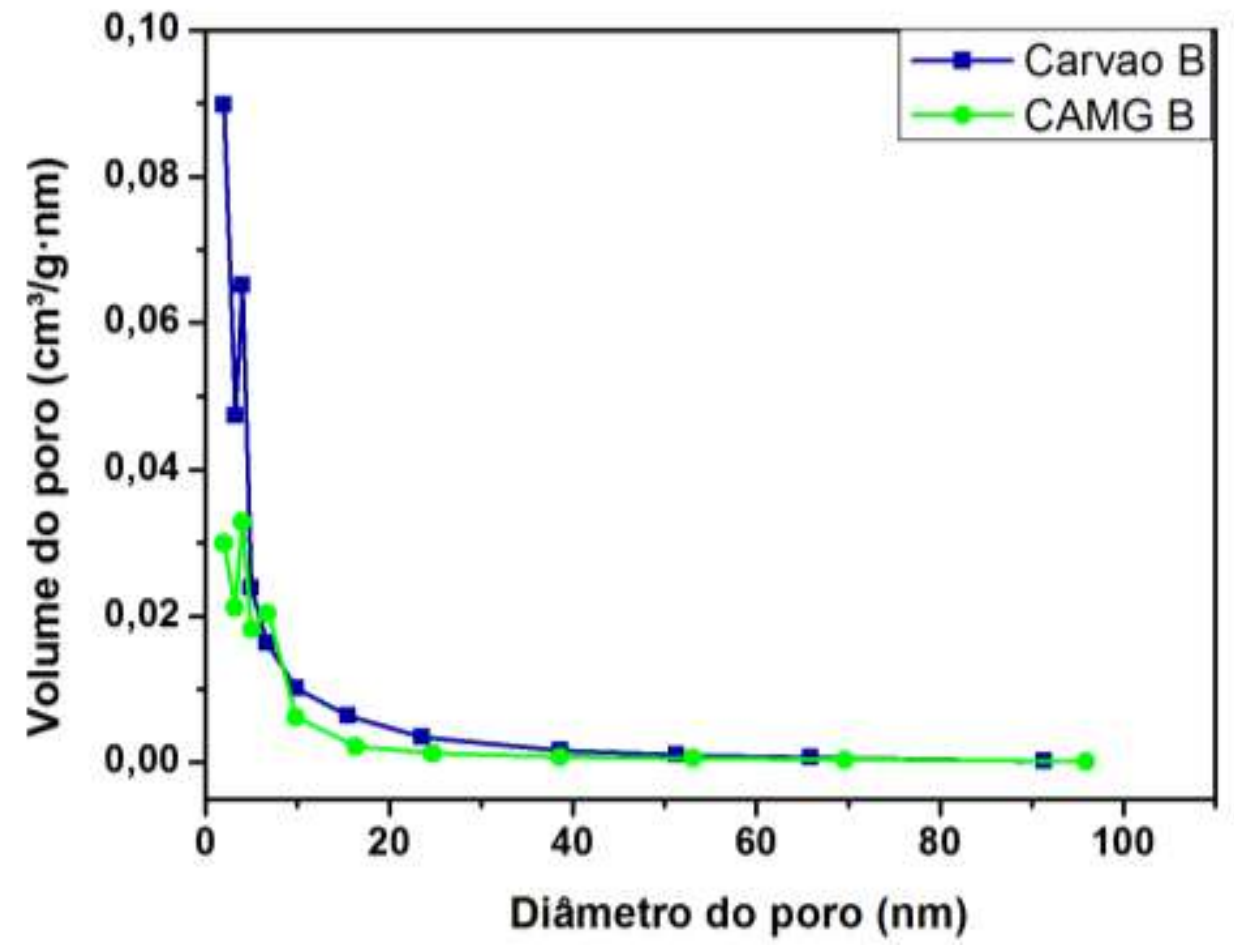

Figura 16 - Distribuição de poro por volume - Carvão B e CAMG B.

As curvas de distribuição do diâmetro do poro por volume, apresentadas nas figuras 15 e 16, demonstraram que há uma diminuição do volume de microporo após a impregnação com a magnetita em cada carvão utilizado como suporte, isso tanto para o carvão A em relação ao CAMG A e para o carvão B em relação ao CAMG B. Essa redução do volume torna-se mais evidente no CAMG B. Na tabela 4, são mostrados os valores de área superficial e de volumes dos microporos para cada tipo de carvão ativado A e B, e também para os carvões magnéticos CAMG A e CAMG B.

$\begin{array}{lcr}\text { Tipo de Carvão } & \text { Área Superficial }\left(\mathrm{m}^{2} / \mathrm{g}\right) & \text { Volume de Microp } \\ \text { Carvão A } & 736,50 & 0,244 \\ \text { CAMG A } & 437,15 & 0,127 \\ \text { Carvão B } & 855,36 & 0,290 \\ \text { CAMG B } & 320,39 & 0,085\end{array}$

Tabela 4 - Valores de área superficial e de volume de microporos de cada carvão ativado e carvão magnético trabalhados. 
De acordo com a tabela, ocorreu uma redução de volume do microporo de $0,244 \mathrm{~cm}^{3} / \mathrm{g}$ no carvão A para $0,127 \mathrm{~cm}^{3} / \mathrm{g}$ no CAMG A, diminuindo $47,95 \%$ do seu volume após a impregnação. Já o carvão B sofreu uma redução de volume de 0,290 $\mathrm{cm}^{3} / \mathrm{g}$ para $0,085 \mathrm{~cm}^{3} / \mathrm{g}$, mostrando uma redução de $70,68 \%$ do seu volume inicial. Isso demonstrou que o volume dos poros do CAMG B foi ocupado pela magnetita após formação do carvão magnético. Esse fato corrobora com a perda considerável de área de superfície no CAMG B $\left(320,39 \mathrm{~m}^{2} / \mathrm{g}\right)$ em relação ao CAMG A $\left(437,15 \mathrm{~m}^{2} / \mathrm{g}\right)$ e também com o maior teor de $\mathrm{Fe}_{3} \mathrm{O}_{4}$ observado, na análise de ICP - OES, no CAMG B do que no CAMG A. Fazendo uma comparação das relações de área de superfície dos carvões A e B com as respectivas dosagens de CAMG A e CAMG B: Carvão A $\left(736,50 \mathrm{~m}^{2} / \mathrm{g}\right) /$ CAMG A $(29,63 \%)=24,86$ e Carvão B $\left(855,36 \mathrm{~m}^{2} / \mathrm{g}\right) /$ CAMG B $(36,48 \%)=23,45$, observam-se resultados muito próximos, demonstrando que os valores de área de superfície são proporcionais aos de teor de $\mathrm{Fe}_{3} \mathrm{O}_{4}$ nos carvões magnéticos.

\subsection{Metodologia para Determinação de BPA em amostras padrão}

Inicialmente, para otimizar a faixa de comprimento de onda e de $\mathrm{pH}$ para análise do BPA, espectros foram registrados em função do $\mathrm{pH}$. Na figura 17 a seguir, os espectros em função do $\mathrm{pH}$, são apresentados para uma concentração de $20 \mathrm{mg} / \mathrm{L}$ de solução de BPA. A partir desses resultados, em diferentes níveis de $\mathrm{pH}(2,4,6,7,8,9$, 10, 11 e 12), foram tomadas as absorbâncias para cada comprimento de onda específico em 226, 243, 277 e 293 nm característicos do espectro de UV-VIS do BPA. Isto permitiu obter outro gráfico na forma de ajuste (gráfico menor inserido no canto direito da figura) onde foram plotadas as absorbâncias versus o pH. O gráfico da absorbância 
pelo comprimento de onda exibe dois comprimentos (226 $\mathrm{nm}$ e $277 \mathrm{~nm}$ ) que podem ser usados para a determinação do BPA, contudo, próximo a banda de $226 \mathrm{~nm}$ ocorre ressonância que pode interferir na determinação. Além disso, neste mesmo gráfico apresenta-se pouca ressonância em 277 nm, fator mais favorável para a determinação do BPA. Já no gráfico das absorbâncias versos o pH, observa-se que o comprimento em $277 \mathrm{~nm}$ exibe uma faixa praticamente linear de análise para quase todos os $\mathrm{pHs}$ analisados, revelando mais um aspecto positivo para a escolha do comprimento de 277 nm para a determinação da concentração do BPA.

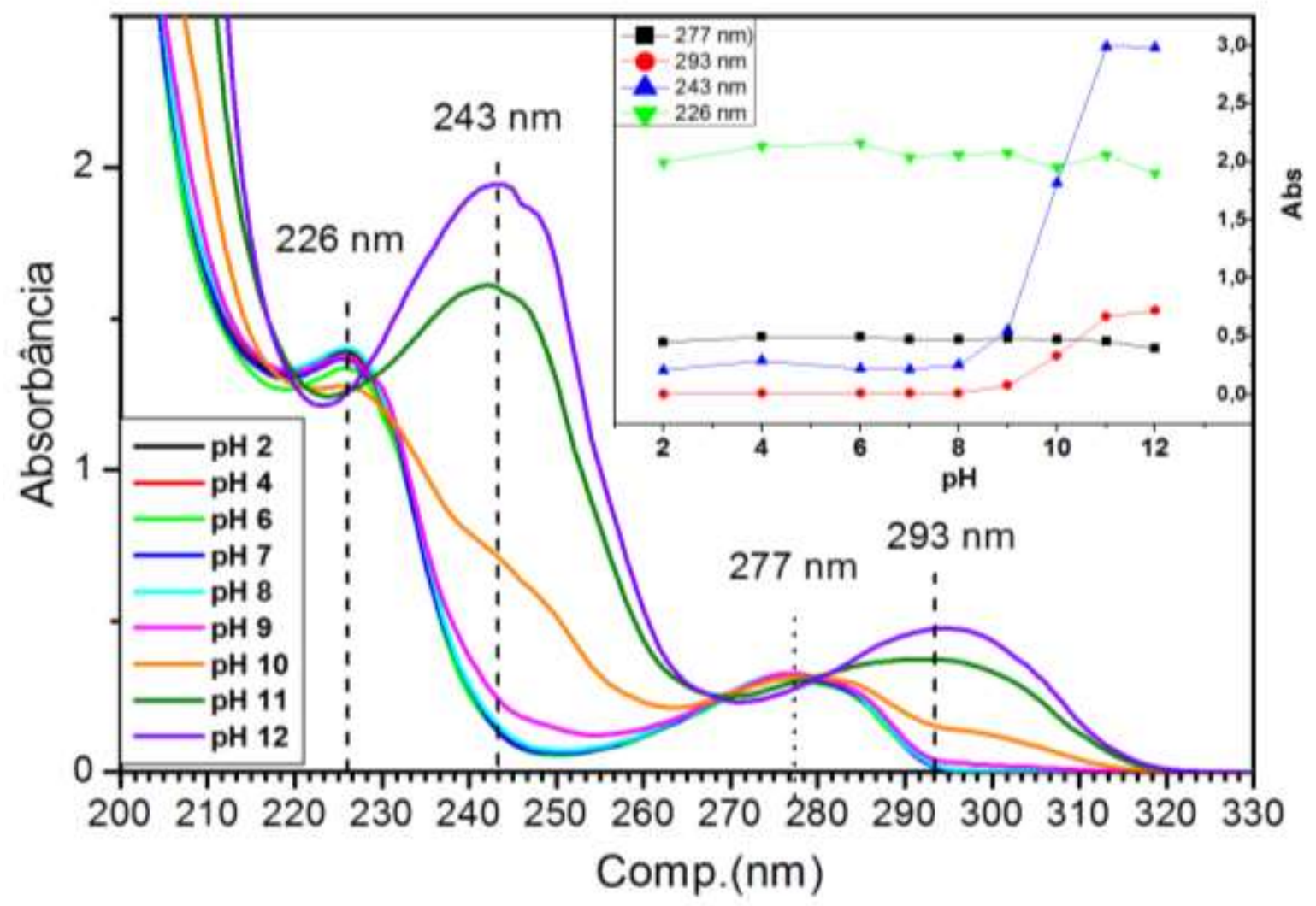

Figura 17 - Gráfico mostrando as absorbâncias do BPA puro em diferentes pHs e um insert no canto superior direito, mostrando a relação de absorbâncias em diferentes comprimentos de onda $(\lambda)$ para todos os pHs medidos. 


\subsubsection{Construção da curva de calibração para o BPA}

Baseando-se na escolha do comprimento de onda mais favorável, foi feita uma curva de calibração com a solução padrão de BPA, preparada conforme o item 3.3, cujo as concentrações foram de 0,$5 ; 1,0 ; 2,5 ; 5,0 ; 7,5 ; 10,0 ; 20,0 ; 30,0 ; 40,0 ; 50,0 \mathrm{mg} / \mathrm{L}$, medidas num comprimento de onda de $277 \mathrm{~nm}$. A figura 18 mostra os parâmetros experimentais ajustados por regressão linear e um $R^{2}=0,9999$, considerado muito bom para determinação do analito.

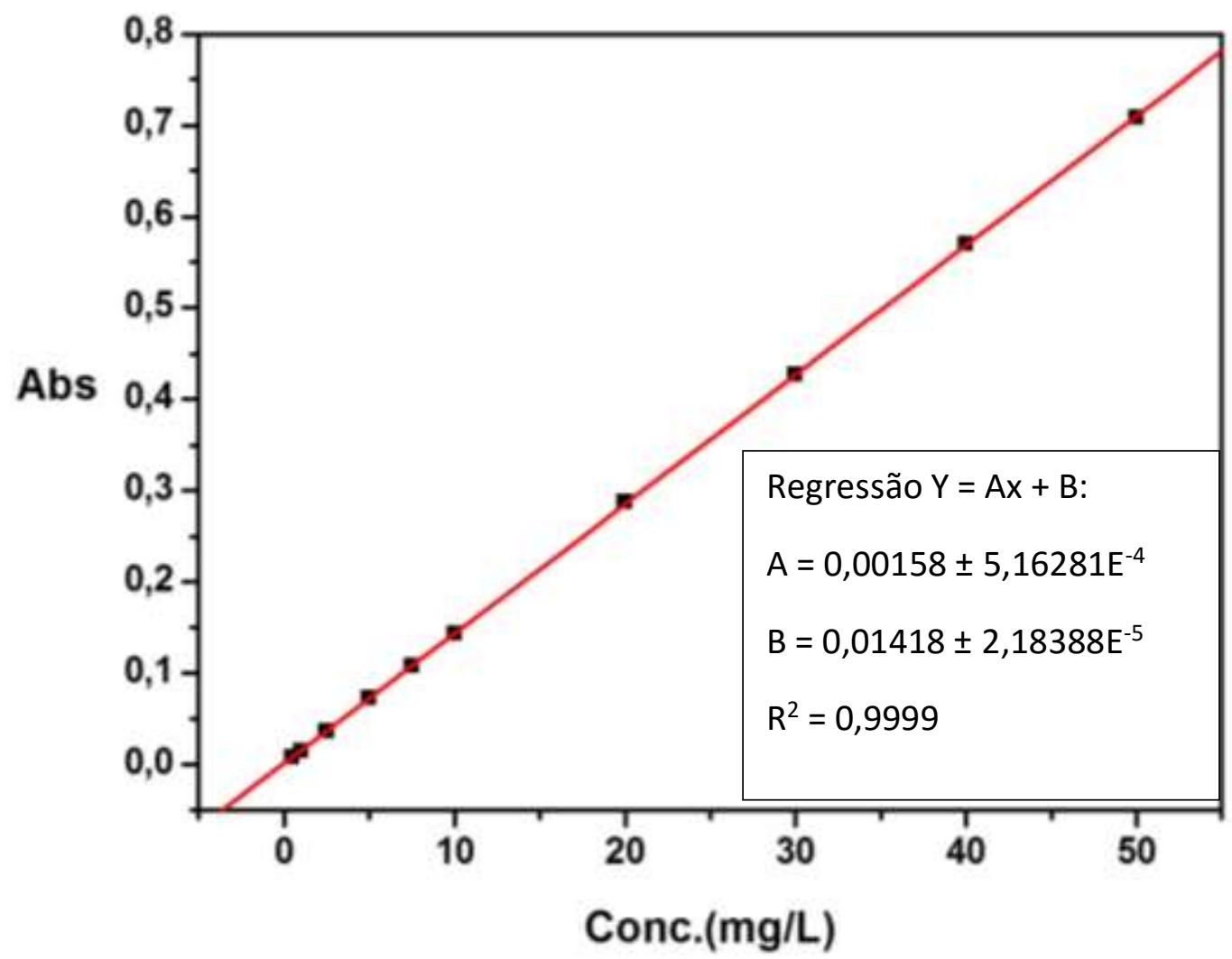

Figura 18 - Calibração utilizando a solução padrão de BPA. Também encontramos um insert no canto inferior direito da figura mostrando os parâmetros de regressão e seus respectivos erros: o coeficiente linear $(A)=0,00158$ $\pm 5,16 \mathrm{E}^{-4}$ e intercepto $(\mathrm{B})=0,01418 \pm 2,18 \mathrm{E}^{-5} ; \mathbf{R}^{2}=0,9999$. 


\subsection{Estudos de remoção por adsorção}

Conforme detalhado na parte experimental, a adsorção do BPA foi investigada em função da agitação, razão BPA/CAMG, tempo de contato e do pH.

\subsubsection{Isotermas de Adsorção (Efeito da Agitação)}

Na figura 19, relaciona-se a eficiência de remoção (\%) de BPA pelo $\mathrm{C}_{\mathrm{np}}(\mathrm{mg} / \mathrm{L})$ que corresponde a quantidade de CAMG A (em $\mathrm{mg}$ ) por litro da solução correspondente. No gráfico, observam-se duas curvas: uma para remoção com agitação por vórtex (cor preta) e outra para agitação por tombamento (cor vermelha). Nos dois métodos, a eficiência se eleva com o aumento da quantidade de CAMG A aplicado na solução de BPA e os máximos de eficiência obtidos com cada tipo de agitação não se apresentam muito diferentes com $99,1 \%$ para o vórtex e $99,3 \%$ para o tombamento.

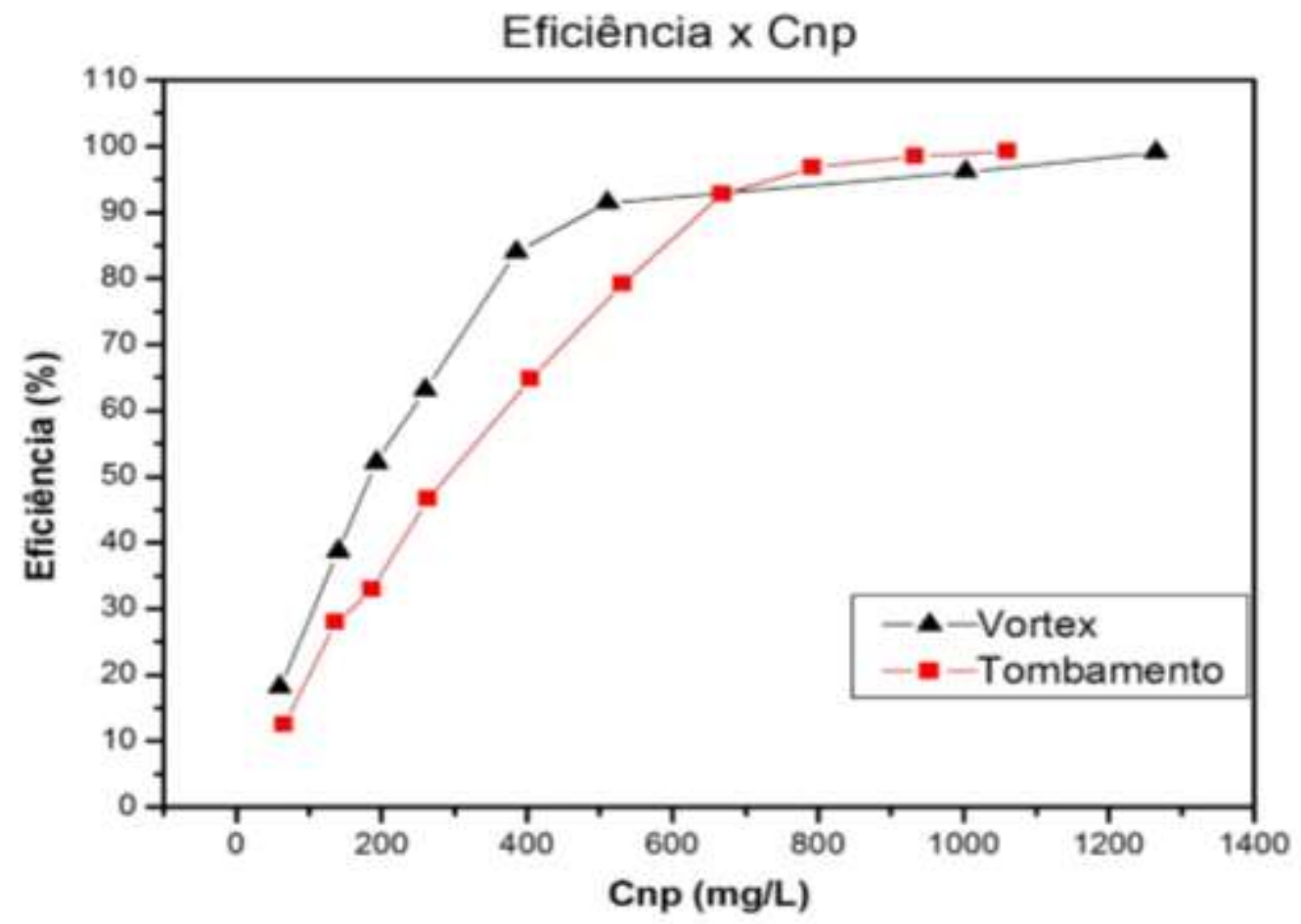

Figura 19 - Gráfico de eficiência de remoção em função do $C_{n p}$. 
Um fator relevante observado é que, inicialmente na agitação vórtex, as eficiências de remoção são maiores que na agitação tombamento com praticamente a mesma quantidade de carvão adicionado.

\begin{tabular}{|c|c|c|c|}
\hline \multicolumn{4}{|c|}{ Eficiência de remoção (Vórtex) } \\
\hline $\mathbf{C}_{\mathbf{0}}(\mathbf{m g} / \mathbf{L})$ & $\mathbf{C e}(\mathbf{m g} / \mathbf{L})$ & $\mathbf{C n p}(\mathbf{m g} / \mathbf{L})$ & $\begin{array}{c}\left(\mathbf{C}_{\mathbf{0}}-\mathbf{C}_{\mathbf{e}}\right) / \mathbf{C}_{\mathbf{0}} \\
\text { Eficiência }(\%)\end{array}$ \\
\hline 20,00 & 16,37 & 60 & 18,17 \\
\hline 20,00 & 12,26 & 140 & 38,70 \\
\hline 20,00 & 9,56 & 192 & 52,18 \\
\hline 20,00 & 7,37 & 260 & 63,15 \\
\hline 20,00 & 3,19 & 385 & 84,04 \\
\hline 20,00 & 1,71 & 510 & 91,45 \\
\hline 20,00 & 0,78 & 1002 & 96,11 \\
\hline 20,00 & 0,19 & 1265 & 99,07 \\
\hline
\end{tabular}

Tabela 5 - Parâmetros de remoção na agitação vórtex.

\begin{tabular}{|c|c|c|c|}
\hline \multicolumn{4}{|c|}{ Eficiência de Remoção (Tombamento) } \\
\hline $\mathrm{C}_{0}(\mathrm{mg} / \mathrm{L})$ & $\mathrm{Ce}(\mathrm{mg} / \mathrm{L})$ & $\operatorname{Cnp}(\mathrm{mg} / \mathrm{L})$ & $\begin{array}{c}\left(\mathrm{C}_{0}-\mathrm{C}_{\mathrm{e}}\right) / \mathrm{C}_{0} \\
\text { Eficiência }(\%)\end{array}$ \\
\hline 40,00 & 35,03 & 66 & 12,42 \\
\hline 40,00 & 28,85 & 137 & 27,88 \\
\hline 40,00 & 26,85 & 187 & 32,88 \\
\hline 40,00 & 21,35 & 263 & 46,63 \\
\hline 40,00 & 14,09 & 405 & 64,77 \\
\hline 40,00 & 8,33 & 532 & 79,17 \\
\hline 40,00 & 2,90 & 668 & 92,74 \\
\hline 40,00 & 1,26 & 792 & 96,84 \\
\hline 40,00 & 0,61 & 934 & 98,48 \\
\hline 40,00 & 0,30 & 1061 & 99,26 \\
\hline
\end{tabular}

Tabela 6 - Parâmetros de remoção para a agitação tombamento. 
Contudo, na agitação por tombamento, no final da remoção, as eficiências vão se tornando maiores. Nos dois tipos de agitação, a remoção de BPA através do CAMG A mostra-se bastante eficiente pelos valores, conforme também são mostrados nas tabelas 5 e 6, relativas aos dados do gráfico da Figura 19.

Além da eficiência de remoção, as interações entre material adsorvente e adsorvido também podem ser avaliadas por meio de isotermas quando o processo de adsorção entra em equilíbrio. Os tipos de agitação utilizados na adsorção de BPA pelo carvão adsorvente (CAMG A) foram avaliados por meio dos modelos matemáticos de Langmuir e de Freundlich, bastante utilizados nesse contexto. O modelo de Langmuir assume uma adsorção de superfície homogênea por cobertura monocamada e nenhum outro tipo interação subsequente entre as espécies adsorvidas ${ }^{30}$. A equação representanda por $\frac{c_{e}}{q_{e}}=\frac{1}{q_{m}} c_{e}+\frac{1}{q_{m} K_{L}}$ ilustra as varáveis encontradas neste modelo: onde $C_{e}$ é a concentração de equilíbrio de BPA na solução $(\mathrm{mg} / \mathrm{L}), q_{e}$ corresponde a quantidade de BPA adsorvido em miligramas por grama de carvão magnético aplicado $(\mathrm{mg} / \mathrm{g})$ na solução e é calculada por: $q_{e}=\frac{\left(C_{0}-C_{e}\right) V}{m} ; C_{0}(\mathrm{mg} / \mathrm{L})$ diz respeito à concentração inicial de BPA anteriormente já definida, $K_{L}$ refere-se à constante de Langmuir (L/mg) e está relacionada com a afinidade dos sítios de ligação, e por último, $q_{m}$ representa a capacidade máxima de adsorção do carvão magnético (mg/g). Os valores de $q_{m}$ e $K_{L}$ são calculados pelo ajuste dos dados experimentais com esse modelo.

Já o modelo empírico de Freundlich está baseado na adsorção em superfícies de camadas múltiplas heterogêneas. A equação pode ser descrita como $q_{e}=K_{F} C_{e}^{1 / n}$. Onde $C_{e}$ e $q_{e}$ já foram definidas no modelo de Langmuir anteriormente citado, $K_{F}$ representa a constante de Freundlich que se relaciona com a capacidade de adsorção e $1 / n$ diz respeito a força de adsorção. $\mathrm{O}$ valor de $1 / n$ quantifica o quanto o processo de 
adsorção está favorável e o grau heterogêneo de superfície. Quando os valores de $n>1$, sugere-se que a adsorção é favorável e existe um aumento dessa capacidade, pela criação de novos sítios de adsorção. $K_{F}$ e $n$ podem ser obtidos do ajuste do gráfico de $q_{e}$ versus $C_{e}$.

Os dados experimentais da figura 20 apresentam isotermas para os dois modos de agitação (vortex e tombamento), e que foram ajustados pelos dois modelos descritos anteriormente: Langmuir em azul e Freundlich em vermelho.
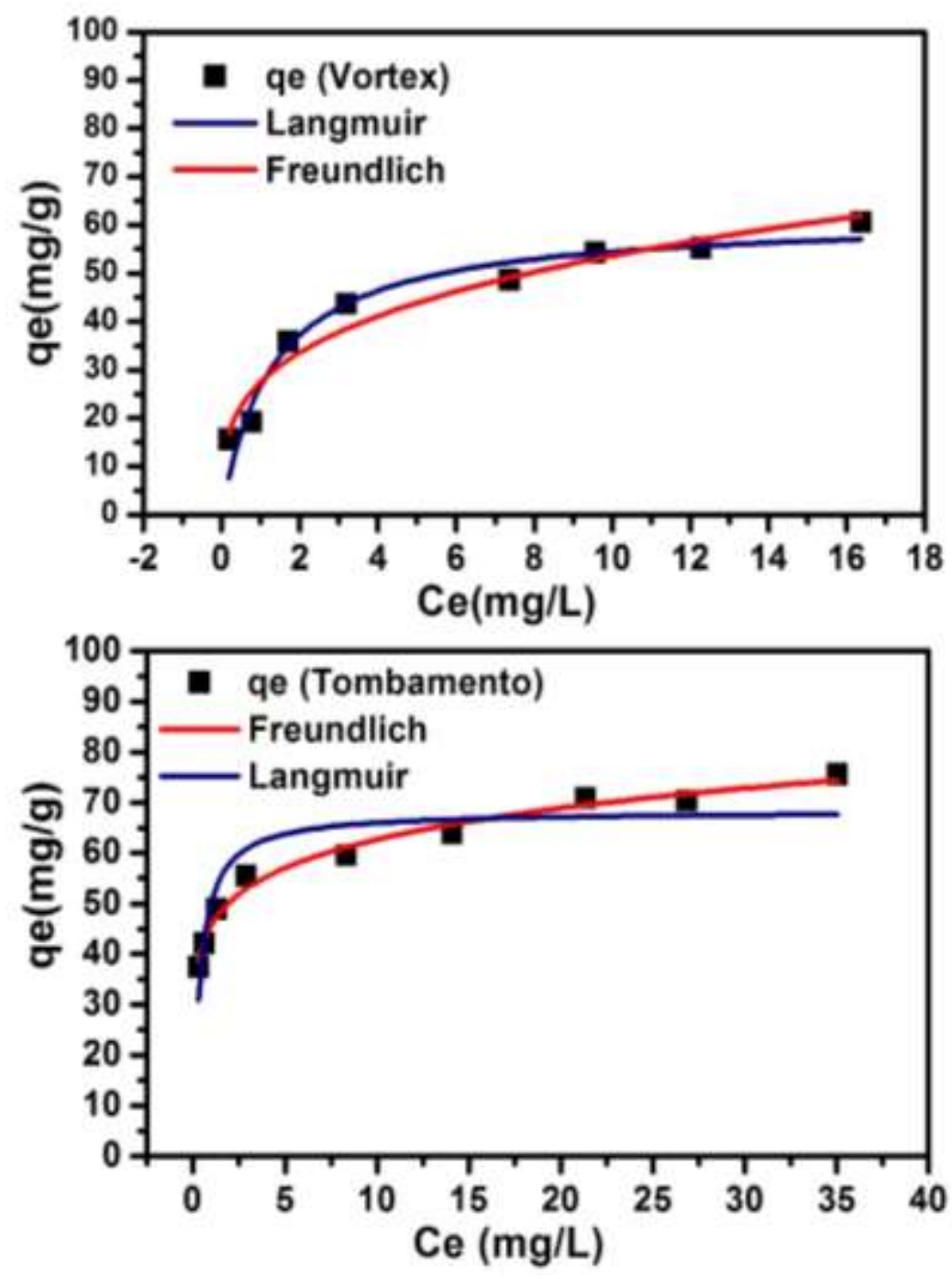

Figura 20 - Gráfico da capacidade de adsorção $\left(q_{e}\right)$ em função da concentração em equilíbrio $\left(C_{e}\right)$ na solução de BPA. 
Na tabela 7, são encontrados parâmetros calculados para os modelos de Langmuir $e$ de Freundlich para os dois modos de agitação.

\begin{tabular}{lcccccc} 
& \multicolumn{3}{c}{ Langmuir } & \multicolumn{5}{c}{ Freundlich } \\
Agitação & $\boldsymbol{q}_{\boldsymbol{m}}(\mathbf{m g} / \mathbf{g})$ & $\boldsymbol{K}_{\boldsymbol{L}}(\mathbf{L} / \mathbf{m g})$ & $\boldsymbol{R}^{2}$ & $\boldsymbol{K}_{\boldsymbol{F}}$ & $\boldsymbol{n}$ & $\boldsymbol{R}^{2}$ \\
Vórtex & $61,64 \pm 3,33$ & $0,76 \pm 0,18$ & 0,9371 & $27,48 \pm 1,99$ & $3,44 \pm 0,39$ & 0,9473 \\
Tombamento & $68,36 \pm 2,59$ & $2,79 \pm 0,69$ & 0,8250 & $45,81 \pm 0,85$ & $7,33 \pm 0,38$ & 0,9825
\end{tabular}

Tabela 7 - Parâmetros para utilizado pelos modelos de Langmuir e Freundlich.

Observando inicialmente os valores do gráfico, na agitação por vórtex, a capacidade máxima de adsorção atinge por volta de 60 mg de BPA por g de CAMG, enquanto que no tombamento esse valor chega próximo de $75 \mathrm{mg}$ de BPA por g de CAMG A, mostrando uma diferença considerável na adsorção e que a agitação é um fator que influencia na capacidade de adsorção do carvão magnético. Analisando os modelos de Langmuir e Freundlich para a agitação por vórtex, não se observam discrepâncias quanto aos valores de $R^{2}$, demonstrando graficamente, uma maior tendência em seguir o modelo de Freundlich. Já no tombamento, os parâmetros de $R^{2}$ se diferem de forma discrepante nos dois modelos matemáticos propostos, apresentando nitidamente uma tendência pela isoterma de Freundlich. Isto mostra que a capacidade de adsorção é regida pelas camadas múltiplas heterogêneas do carvão magnético. Além disso, o valores de $n$ nas duas agitações, apresentam-se maiores que 1 e portando, uma adsorção favorável tanto em vórtex $(n=3,44)$ quanto em tombamento $(n=7,33)$, demonstrando um melhor desempenho na agitação tombamento. Tendo em vista esses dados, avaliou-se maior homogeneidade de resultados para os testes feitos utilizando-se agitação por tombamento, que foi empregada nos próximos experimentos. 


\subsubsection{Isotermas de Adsorção (comparação entre CAMG A e CAMG B)}

Neste momento, será avaliado o desempenho dos diferentes carvões sintetizados (CAMG A e CAMG B) como materiais de remoção de BPA no tratamento da água. Na figura 21, é apresentado um gráfico de eficiência de remoção (\%) pelo Cnp (mg/L). As tabelas 8 e 9 trazem os parâmetos analisados de concentração e de massa para o CAMG A e CAMG B, relativos ao gráfico.

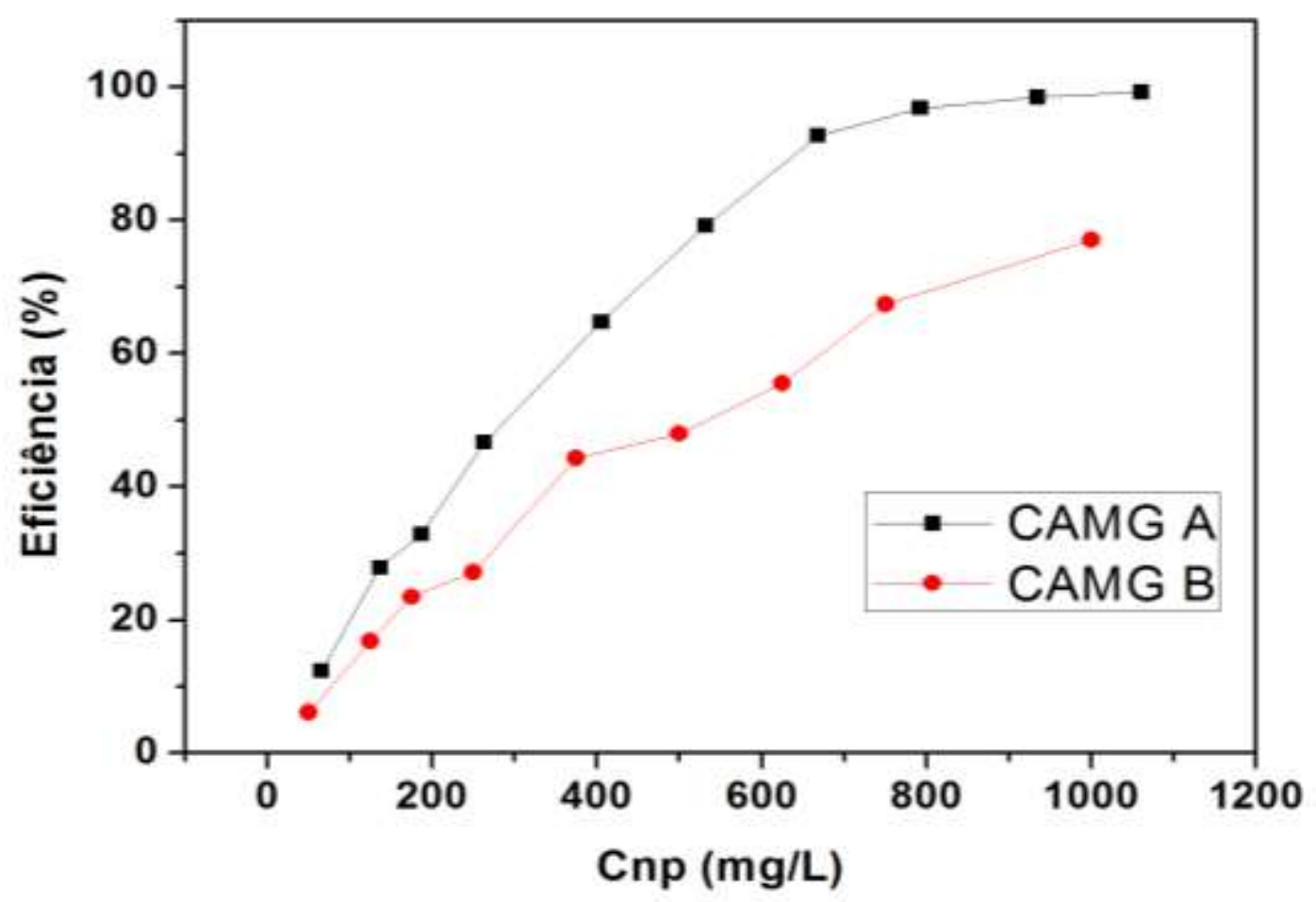

Figura 21 - Gráfico da eficiência de remoção utilizando os carvões CAMG A e CAMG B.

Observando as duas curvas de eficiência na figura 21 e os dados das tabelas 8 e 9 verificam-se diferenças entre os comportamentos entre os dois carvões: a ocorrência de valores distintos nas eficiências máximas de adorsão entre os mesmos, com 99,3\% para o CAMG A e 77,1\% para o CAMG B. Outro aspecto relevante, seriam as iclinações apresentadas por cada curva: para o CAMG A, a curva mostra-se menos 
incinada com saturação; já para o CAMG B, a curva é mais inclinada, sem saturação ou com saturação bem mais difícil de ser alcançada.

Eficiência de remoção - Tombamento- CAMG A

\begin{tabular}{|c|c|c|c|}
\hline $\mathbf{C}_{\mathbf{0}}(\mathbf{m g} / \mathbf{L})$ & $\mathbf{C e}(\mathbf{m g} / \mathbf{L})$ & $\begin{array}{c}\mathbf{C n p} \\
(\mathbf{m g} / \mathbf{L})\end{array}$ & $\begin{array}{c}\left(\mathbf{C}_{\mathbf{0}}-\mathbf{C}_{\mathbf{e}}\right) / \mathbf{C}_{\mathbf{0}} \\
\text { Eficiência }(\mathbf{\%})\end{array}$ \\
\hline 40,00 & & 66 & 12,42 \\
\hline 40,00 & 35,03 & 137 & 27,88 \\
\hline 40,00 & 28,85 & 187 & 32,88 \\
\hline 40,00 & 26,85 & 263 & 46,63 \\
\hline 40,00 & 21,35 & 405 & 64,77 \\
\hline 40,00 & 14,09 & 532 & 79,17 \\
\hline 40,00 & 8,33 & 668 & 92,74 \\
\hline 40,00 & 2,90 & 792 & 96,84 \\
\hline 40,00 & 1,26 & 934 & 98,48 \\
\hline 40,00 & 0,61 & 1061 & 99,26 \\
\hline
\end{tabular}

Tabela 8 - Parâmetros de remoção para o CAMG A na agitação tombamento.

\begin{tabular}{|c|c|c|c|}
\hline & \multicolumn{3}{|c|}{ Eficiência de remoção - Tombamento- CAMG B } \\
\hline $\mathbf{C}_{\mathbf{0}}(\mathbf{m g} / \mathbf{L})$ & $\mathbf{C e}(\mathbf{m g} / \mathbf{L})$ & $\mathbf{C n p}(\mathbf{m g} / \mathbf{L})$ & $\begin{array}{c}\left(\mathbf{C}_{\mathbf{0}}-\mathbf{C}_{\mathbf{e}}\right) / \mathbf{C}_{\mathbf{0}} \\
\text { Eficiência }(\%)\end{array}$ \\
\hline 40,00 & 37,55 & 50 & 6,12 \\
\hline 40,00 & 33,27 & 125 & 16,81 \\
\hline 40,00 & 30,61 & 175 & 23,46 \\
\hline 40,00 & 29,14 & 250 & 27,14 \\
\hline 40,00 & 22,28 & 375 & 44,30 \\
\hline 40,00 & 20,81 & 500 & 47,98 \\
\hline 40,00 & 17,79 & 625 & 55,51 \\
\hline 40,00 & 13,03 & 750 & 67,42 \\
\hline 40,00 & 9,18 & 1000 & 77,05 \\
\hline
\end{tabular}

Tabela 9 - Parâmetros de remoção para o CAMG B na agitação tombamento. 
Conforme utilizado para avaliar o critério de diferentes agitações utilizadas na adsorção de BPA, na comparação entre os dois carvões, também serão avaliados pelos modelos matemáticos de Langmuir e Freundlich para ajuste dos dados.
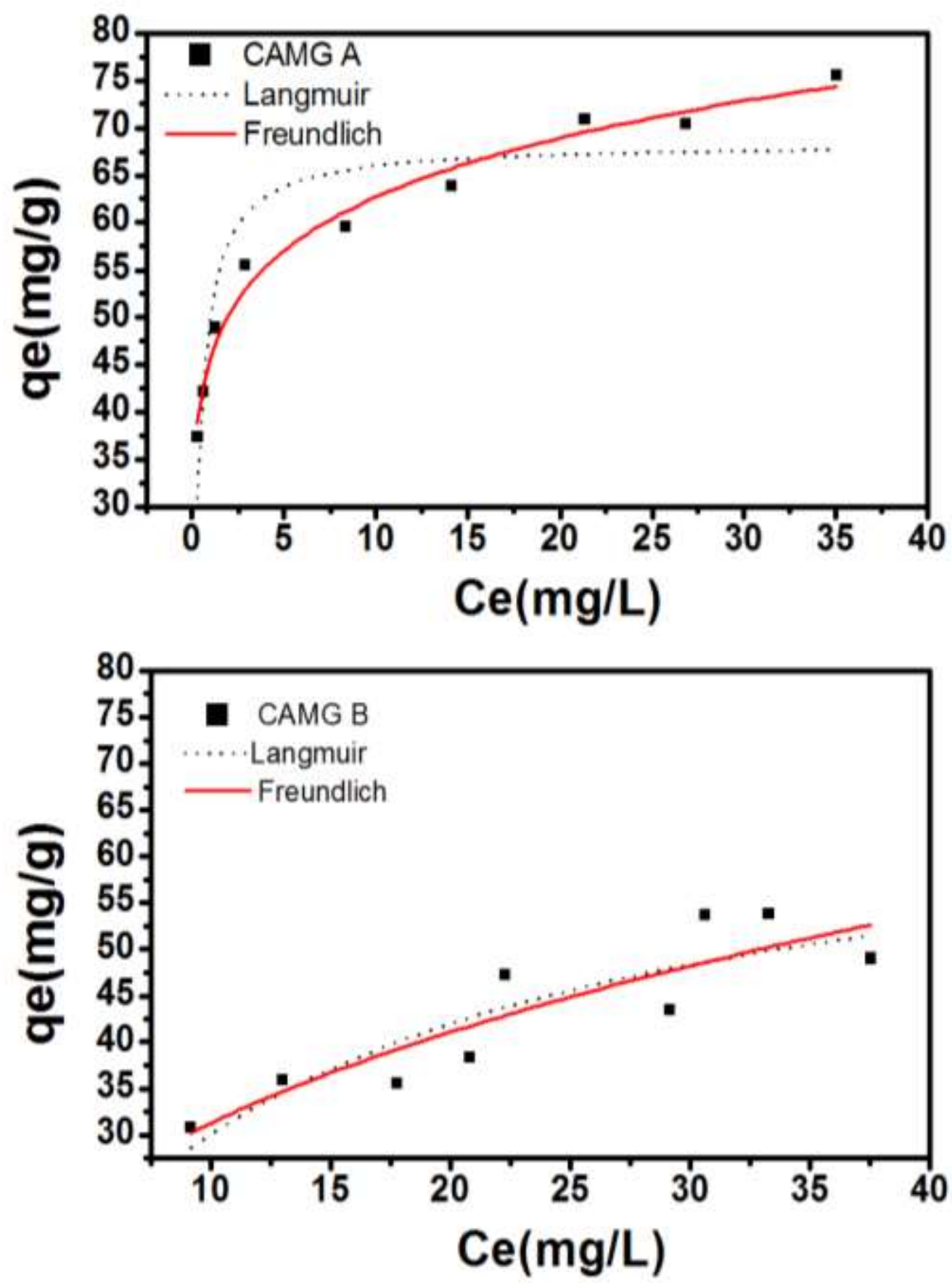

Figura 22 - Isotermas de adsorção de Langmuir e Freundlich para os carvões magnéticos CAMG A e CAMG B. 
Na tabela 10, são encontrados os valores de cada modelo aplicado para os dois tipos de carvões magnéticos:

\begin{tabular}{lcccccc} 
& \multicolumn{3}{c}{ Langmuir } & \multicolumn{5}{c}{ Freundlich } \\
Carvão & $\boldsymbol{q}_{\boldsymbol{m}}(\mathbf{m g} / \mathbf{g})$ & $\boldsymbol{K}_{\boldsymbol{L}}(\mathbf{L} / \mathbf{m g})$ & $\boldsymbol{R}^{2}$ & $\boldsymbol{K}_{\boldsymbol{F}}$ & $\boldsymbol{n}$ & $\boldsymbol{R}^{2}$ \\
CAMG A & $68,26 \pm 2,59$ & $2,79 \pm 0,69$ & 0,8250 & $45,81 \pm 0,85$ & $7,33 \pm 0,38$ & 0,9825 \\
CAMG B & $69,49 \pm 9,23$ & $0,08 \pm 0,03$ & 0,7470 & $12,62 \pm 3,32$ & $2,54 \pm 0,53$ & 0,7640
\end{tabular}

\section{Tabela 10 - Parâmetros de análise para os modelos de Langmuir e Freundlich para o CAMG A e o CAMG B.}

Nos dois carvões analisados, o modelo mais adequado foi o de Freundlich, visto que os valores de $R^{2}$ foram melhores para este modelo. Tanto os valores de $R^{2}$ e da onstante de Freundlich $\left(K_{F}\right)$ para o CAMG A foram mais elevados que no CAMG B. Observando os dois gráficos e comparando os dados da tabela 10, o CAMG A adapta-se melhor aos dois modelos (Langmuir e Freundlich) com pontos mais alinhados que o GAMG B, que apresenta pontos mais dispersos, não havendo diferenças significativas entre os dois modelos para o CAMG B. Além disso, o valor de $n$ também se apresentou maior no CAMG A $(n=7,33)$ do que no CAMG B $(n=2,54)$ indicando um melhor desempenho do carvão CAMG A na avaliação da capacidade de adsorção.

\subsubsection{Cinética de Adsorção (Efeito da Agitação)}

Atualmente, para um melhor entendimento dos mecanismos de adsorção, dois modelos cinéticos de adsorção são descritos de duas formas bem características: o primeiro é a pseudo de primeira ordem e o outro, é a pseudo de segunda ordem. A equação da pseudo de primeira ordem é descrita conforme a expressão: $\ln \left(q_{e}-q_{t}\right)=\ln q_{e}-k_{1} t$. Onde $q_{e}$ e $q_{t}$ correspondem a quantidade de BPA adsorvida 
na superfície do carvão na solução em equilbrio e $k_{1}$ representa a constante de velocidade do modelo de primeira ordem por hora $(1 / h)$, sendo $q_{e}(\mathrm{mg} / \mathrm{g})$ descrita como a capacidade de adsorção do carvão magnético e calculada como já mencionado anteriormente: $q_{e}=\frac{\left(C_{0}-C_{e}\right) V}{m} ; C_{0}(\mathrm{mg} / \mathrm{L})$ é concentração inicial da solução de BPA e $C_{e}(\mathrm{mg} / \mathrm{L})$ é a concentração de equilíbrio da solução de BPA, $m$ corresponde a massa de partícula adsorvente adicionada (g) ao sistema e $V$ refere-se ao volume da solução (L). Já $q_{t}$ pode ser descrita como: $q_{t}=\frac{\left(C_{0}-C_{t}\right) V}{m}$. Onde $C_{0}(\mathrm{mg} / \mathrm{L})$ é a concentração inicial na solução de BPA, $C_{t}$ é concentração em equilíbrio medida no tempo $\mathrm{t}(\mathrm{h}), V$ o volume da solução (L) e $m$ é massa aplicada de carvão magnético adsorvente (g).

A pseudo de segunda ordem corresponde a todos os passos de adsorção incluindo difusão no filme externo, adsorção e difusão de partículas interna, pode ser descrita segundo a equação: $\frac{1}{q_{t}}=\frac{1}{k_{2} q_{e}^{2}}+\frac{t}{q_{e}}$. Onde $q_{t}$ e $q_{e}$ já foram definidas na pseudo de primeira ordem como as capacidades de adsorção de BPA do carvão magnético no tempo e em equilíbrio $(\mathrm{mg} / \mathrm{g})$, respectivamente, $t$ corresponde ao tempo de interação (h) e $k_{2}$ refere-se à constante do modelo de pseudo de segunda ordem (g/mg.h). Além disso, a taxa de adsorção inicial $\mathrm{h}(\mathrm{mg} / \mathrm{g} . \mathrm{h})$ pode ser determinada a partir de $h=k_{2 .} q_{e . .}^{2}$

$\mathrm{Na}$ figura 22, verificam-se dois gráficos comparando a cinética de duas formas de agitação já citados anteriormente: vórtex e tombamento. Nestes gráficos nota-se que, na agitação vórtex, o equilíbrio começa a ser atingido em 0,8 h (ou 48 minutos) de interação, mais rápido que na agitação tombamento onde o equilíbrio começa a ser atingido em $1 \mathrm{~h}$ (ou 60 minutos), aproximadamente, na interação entre o CAMG A e a solução de BPA. Apesar disso, na agitação por tombamento, consegue-se trabalhar com escalas maiores de capacidade de adsorção quando $q_{t}$ atinge próximo de $66 \mathrm{mg}$ de BPA por grama de carvão magnético, contra próximo de 37 mg de BPA por grama de carvão 
magnético na agitação vórtex. Outro aspecto relevante é nos primeiros minutos de interação, com a agitação tombamento, o carvão magnético retira 53 mg de BPA e, na agitação vórtex, retira-se por volta de $30 \mathrm{mg}$.
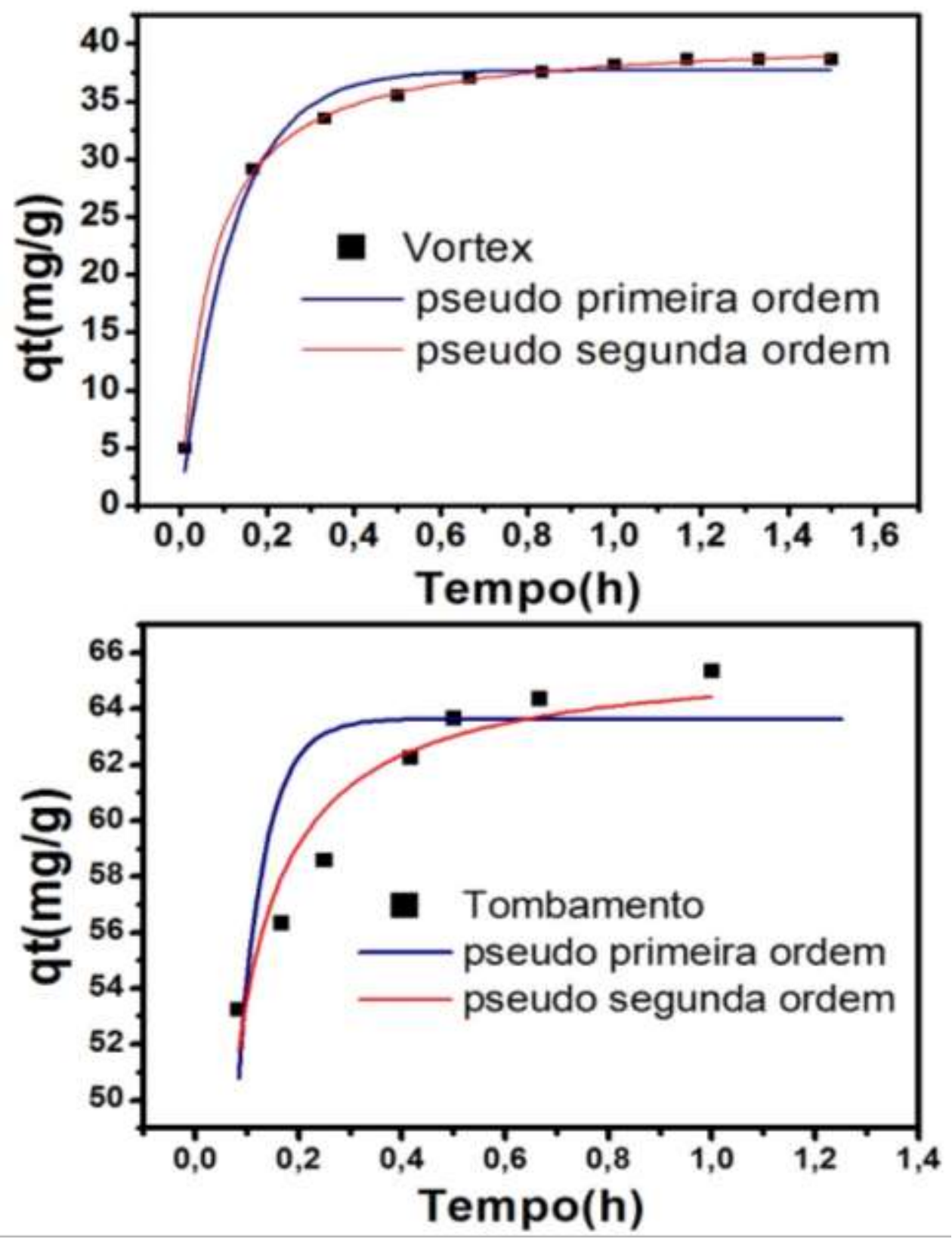

Figura 23 - Cinética de adsorção (tempo de contato) para os modos de agitação em vórtex e tombamento.

Na tabela 11, encontram-se os valores das constantes para as pseudos de primeira e segunda ordens respectivamente: 


\begin{tabular}{lcccccc} 
& \multicolumn{3}{c}{ Pseudo de Primeira Ordem } & \multicolumn{3}{c}{ Pseudo de Segunda Ordem } \\
Agitação & $\boldsymbol{k}_{\mathbf{1}}(\mathbf{1} / \mathbf{h})$ & $\boldsymbol{q}_{\boldsymbol{e} \mathbf{1}}(\mathbf{m g} / \mathbf{g})$ & $\boldsymbol{R}^{2}$ & $\boldsymbol{k}_{\mathbf{2}}(\mathbf{g} / \mathbf{m g} . \mathbf{h})$ & $\boldsymbol{q}_{\boldsymbol{e} \mathbf{2}}(\mathbf{m g} / \mathbf{g})$ & $\boldsymbol{R}^{2}$ \\
Vórtex & $8,33 \pm 0,82$ & $37,71 \pm 0,51$ & 0,9838 & $0,36 \pm 0,01$ & $40,64 \pm 0,13$ & 0,9995 \\
Tombamento & $19,17 \pm 3,04$ & $63,64 \pm 1,20$ & 0,5507 & $65,9 \pm 0,94$ & $0,66 \pm 0,11$ & 0,9054 \\
\hline
\end{tabular}

Tabela 11- Tempo de contato entre o CAMG e a solução de BPA.

Analisando os dados da tabela, verifica-se que a pseudo de segunda ordem se ajusta melhor nos dois métodos de agitação do que a pseudo de primeira ordem, com $R^{2}$ iguais a 0,9995 para vórtex e 0,9055 para tombamento. A taxa inicial de adsorção $(h)$ foi, aproximadamente, 20 vezes maior no vórtex com $h=594,57 \mathrm{mg} / \mathrm{g} \cdot \mathrm{h}$ que no tombamento com $h=28,71 \mathrm{mg} / \mathrm{g}$.h. Portanto, o critério de escolha da agitação irá variar, ou quando há uma preferência por uma cinética mais rápida (no caso do vórtex), ou mais lenta com maior eficiência (no caso do tombamento). Pelos parâmetros observados, a cinética de adsorção do CAMG A segue o modelo de pseudo de segunda ordem e a agitação tombamento apresenta uma adsorção mais lenta em relação ao vórtex, porém, possui um melhor aproveitamento retirando uma maior quantidade do poluente BPA por grama de carvão magnético.

\subsubsection{Cinética de Adsorção (Tempo de contato entre o BPA e os carvões adsorventes)}

Da mesma forma que no estudo de adsorção envolvendo o tipo de agitação, a cinética de cada tipo de carvão também foi avaliada neste trabalho. Na figura 24 , observam-se duas curvas relacionando $q_{t}$ em mg de BPA por grama de carvão versus o tempo (h). Para as duas curvas, o modelo de pseudo de segunda ordem mostrou-se mais adequado do que o modelo de pseudo de primeira ordem. Esta observação torna-se mais 
evidente nos gráficos de cinética do CAMG A e do CAMG B, onde a pseudo de segunda ordem mostra-se bem mais alinhada do que o gráfico da pseudo de primeira ordem.
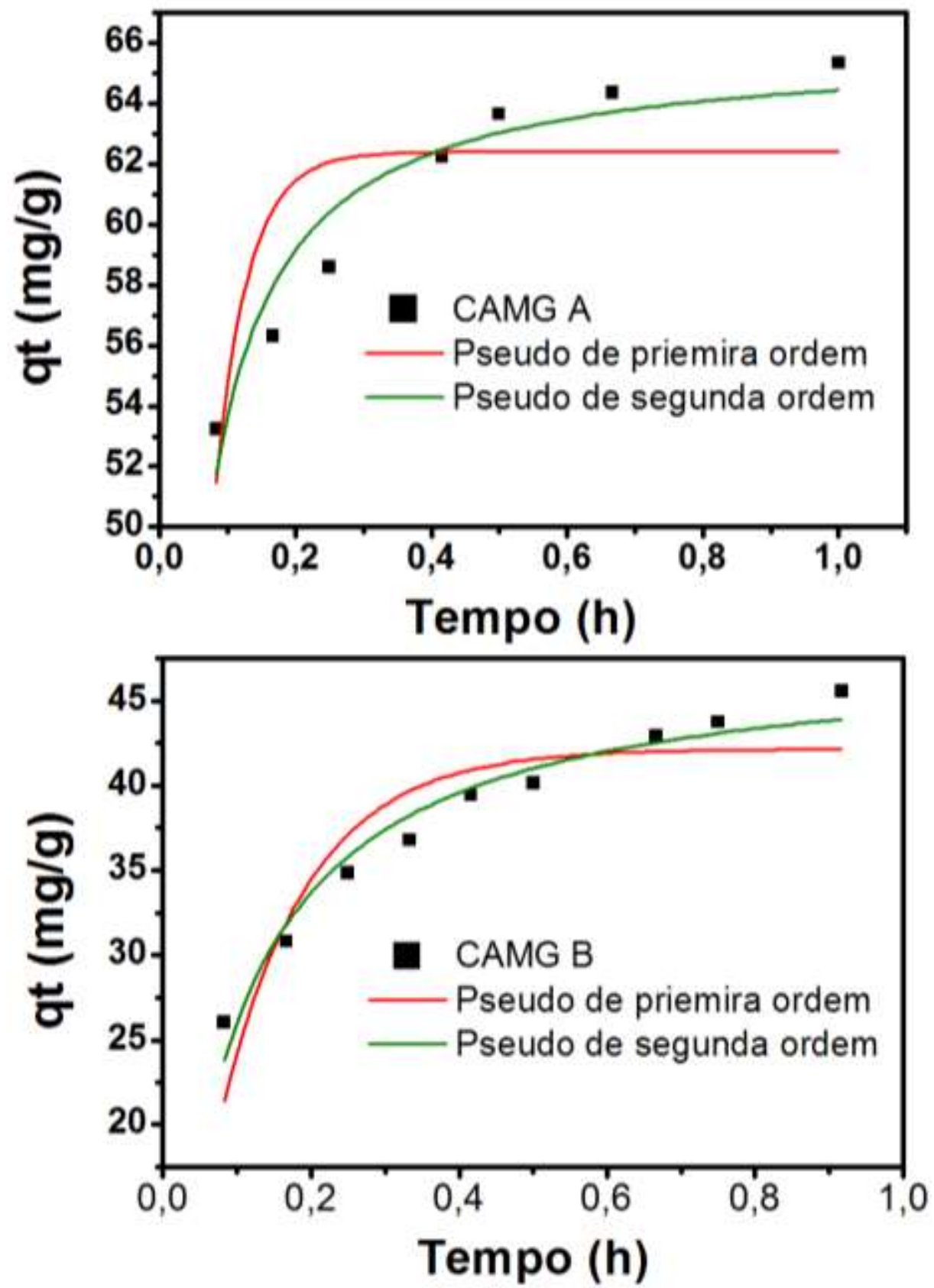

Figura 24 - Gráfico da cinética de adsorção para os carvões magnéticos CAMG A e CAMG B.

O CAMG A apresenta um máximo para se trabalhar até $65 \mathrm{mg}$ de BPA por grama de carvão magnético, já o CAMG B adsorve um máximo de 45 mg de BPA por 
grama de carvão. Nos primeiros 5 minutos, o CAMG A adsorve aproximadamente 53 mg de BPA por grama de carvão magnético, enquanto que o CAMG B adsorve por volta de $26 \mathrm{mg}$ de BPA por grama. Observando as inclinações, o CAMG B apresenta maior inclinação do que o CAMG A, onde a saturação é atingida com maior facilidade no CAMG A. Outro fator observável graficamente, é que o CAMG A adsorve uma maior quantidade de contaminante dentro do mesmo intervalo de tempo. Os parâmetros dos dois gráficos estão descritos na tabela 12 onde podem ser encontradas as constantes de pseudo de primeira ordem e pseudo de segunda ordem.

\begin{tabular}{lcccccc} 
& \multicolumn{2}{c}{ Pseudo de Primeira Ordem } & \multicolumn{3}{c}{ Pseudo de Segunda Ordem } \\
Carvão & $\boldsymbol{k}_{\mathbf{1}}(\mathbf{1} / \boldsymbol{h})$ & $\boldsymbol{q}_{\boldsymbol{e} \mathbf{1}}(\mathbf{m g} / \mathbf{g})$ & $\boldsymbol{R}^{2}$ & $\boldsymbol{k}_{\mathbf{2}}(\mathbf{g} / \mathbf{m g} \cdot \mathbf{h})$ & $\boldsymbol{q}_{\boldsymbol{e} \mathbf{2}}(\mathbf{m g} / \mathbf{g})$ & $\boldsymbol{R}^{2}$ \\
& & & & & & \\
CAMG A & $20,90 \pm 3,57$ & $62,40 \pm 1,34$ & 0,5535 & $0,66 \pm 0,11$ & $65,91 \pm 0,94$ & 0,9055 \\
CAMG B & $8,50 \pm 1,25$ & $42,15 \pm 1,34$ & 0,8034 & $0,54 \pm 0,03$ & $47,96 \pm 1,17$ & 0,9526 \\
\hline
\end{tabular}

Tabela 12 - Parâmetros de tempo de contato para os carvões CAMG A e CAMG B.

Observando os dados, as informações da tabela confirmam o que pode ser constado à primeira vista olhando os gráficos, de que os valores para o CAMG B estão mais ajustados de acordo com os modelos matemáticos que os valores para o CAMG A. Comparando os $R^{2}$ de cada modelo, nota-se que, o CAMG B apresenta valores melhores com $R^{2}=0,8033$ para primeira ordem e $R^{2}=0,9526$ para segunda ordem, contra $R^{2}=0,5535$ para primeira ordem e $R^{2}=0,9055$ para segunda ordem para o carvão CAMG A. Contudo, a taxa inicial de remoção $h=2.867,12 \mathrm{mg} / \mathrm{g} \cdot \mathrm{h}$ para o CAMG A apresentou-se 2 vezes maior que esta taxa $h=1.242,09 \mathrm{mg} / \mathrm{g} . \mathrm{h}$ para o CAMG B. Um aspecto que poderia explicar esta observção na eficiência do CAMG A em relação a do CAMG B, reside no tamanho e na profundidade do volume dos poros da espécie de carvão ativado utilizado na elaboração do carvão magnético. Estes fatores identificados na caracterização por MEV, ICP-OES e pelo BET, influenciam nas características de 
adsorção do material adsorvente. O fato do carvão B apresentar maior volume de poro, dado demonstrado pelo BET, possibilitou que uma quantidade maior de magnetita ocupasse os sítios de adsorção do CAMG B, aspecto comprovado pelo teor medido na análise de ICP-OES. De fato, este fator provocou uma redução da eficiência devido à diminuição, no CAMG B, da quantidade de poros pontencias aptos para a adsorção de BPA. Estes aspectos demonstraram que o tamanho e o volume de poro do carvão são fatores determinantes, tanto para a eficiência de remoção quanto para a cinética entre os carvões magnéticos adsorventes.

\subsection{Influência do pH}

A influência do pH também foi verificada na remoção do BPA. Nessa direção, na figura 25, que mostra a eficiência de remoção em função do $\mathrm{pH}$, é possível notar que essa eficiência é máxima na região que vai de $\mathrm{pH}$ ácido a neutro, mas decai significantemente a partir de $\mathrm{pH} 8$.

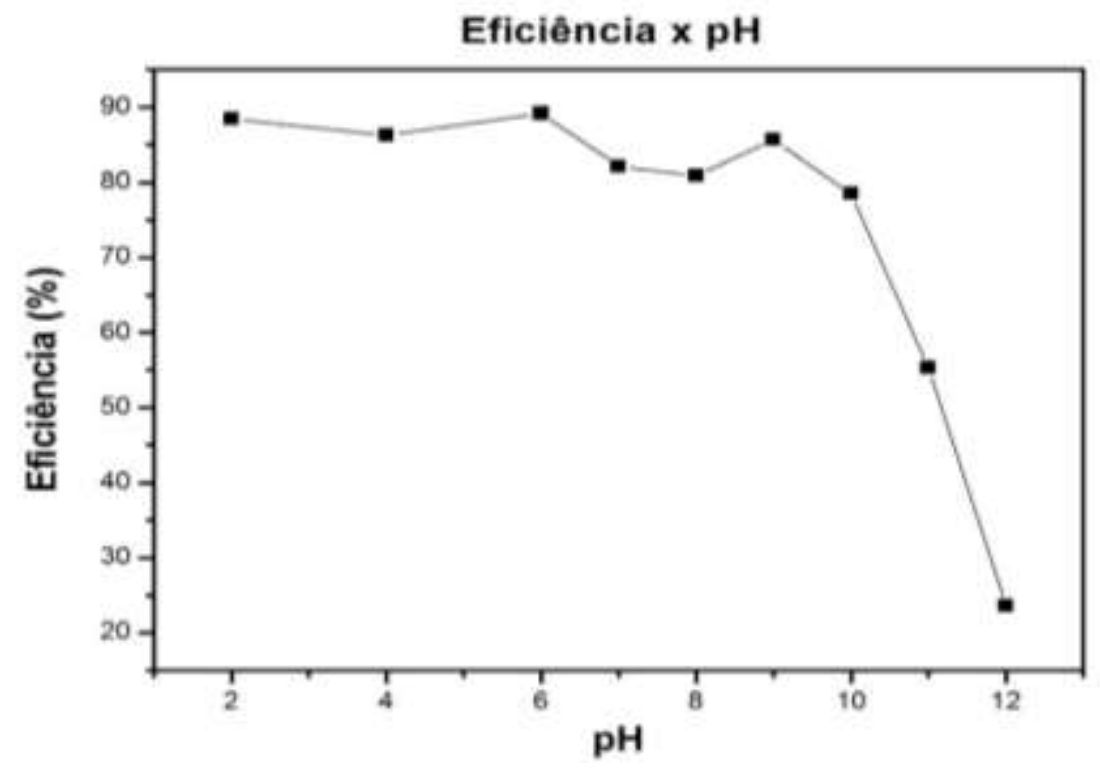

Figura 25 - Gráfico da eficiência de remoção em função do pH. 
Esse comportamento pode ser melhor explicado a partir da especiação do BPA em meio aquoso. Considerando-se que os pKa's dos dois hidrogênios ionizáveis (ligados ao oxigênio) são muito próximos, entre 10 e 11, a figura 26 mostra o percentual de cada espécie em função do pH. Nesse caso, nota-se que, em uma faixa de pH que vai do meio ácido a levemente alcalino, o BPA está praticamente $100 \%$ protonado, aqui representado por $\mathrm{BPAH}_{2}$. A partir de $\mathrm{pH} 8$, essa espécie começa a se desprotonar a $\mathrm{BPAH}^{-} \mathrm{e}$, em $\mathrm{pH} 12$ já está praticamente todo desprotonado na forma de $\mathrm{BPA}^{2-}$, conforme os equilíbrios $\mathrm{BPAH}_{2}+\mathrm{H}_{2} \mathrm{O} \leftrightarrows \mathrm{BPAH}^{-}+\mathrm{H}_{3} \mathrm{O}^{+}$e $\mathrm{BPAH}^{-}+\mathrm{H}_{2} \mathrm{O} \leftrightarrows \mathrm{BPA}^{2-}+$ $\mathrm{H}_{3} \mathrm{O}^{+}$.

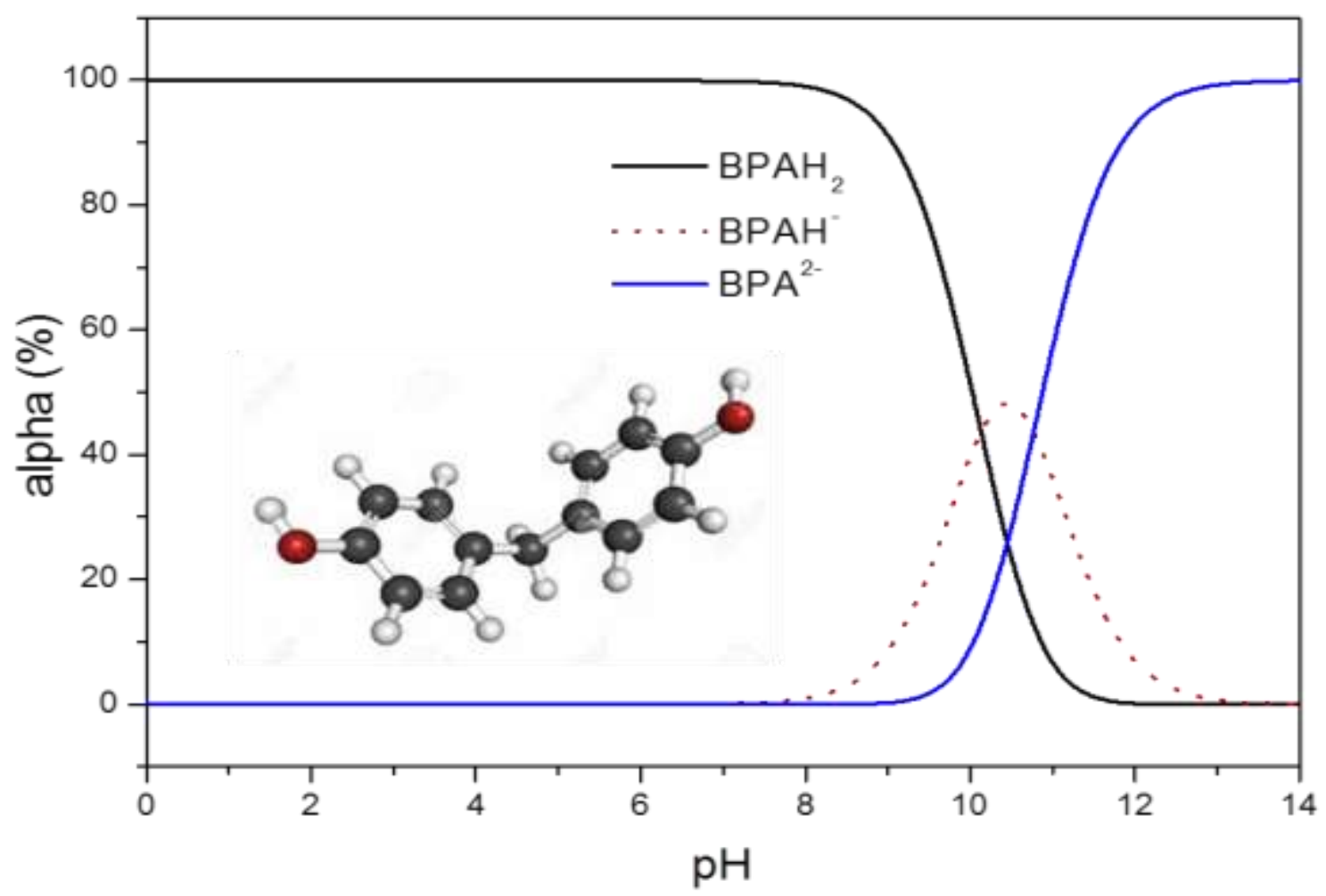

Figura 26 - Especiação para as formas protonada e desprotonada da molécula de BPA.

Conforme já citado anteriormente ${ }^{30}$, o mecanismo de interações $\pi-\pi$ pode ser utilizado para explicar a interação de moléculas orgânicas com duplas ligações (e 
especialmente aromáticas) em superfícies carbonáceas. Dessa forma, pode ser especulado que o BPA, com dois anéis aromáticos que possuem elétrons $\pi$, interagem com os elétrons $\pi$ da superfície por meio de acoplamento $\pi-\pi$, conforme ilustrado na figura 27. Além disso, os grupos hidroxilas residuais, comumente presentes em superfícies carbonáceas tratadas em meio ácido, podem formar ligações de hidrogênio com os hidrogênios das hidroxilas do BPA. Além disso, a superfície dos carvões magnéticos sintetizados nesse trabalho é rica em nanopartículas de $\mathrm{Fe}_{3} \mathrm{O}_{4}$, que também apresentam superfície com grupos hidroxilados $\mathrm{pH}$-dependentes. De fato, a superfície desses óxidos pode ser vista como um ácido diprótico e interpretado pelo modelo de dois pK's (Two-pK Model), conforme reações:

$$
\begin{aligned}
& \equiv \mathrm{MOH}_{2}^{+}+\mathrm{H}_{2} \mathrm{O} \stackrel{\mathrm{pK}_{1}}{\rightleftharpoons}=\mathrm{MOH}+\mathrm{H}_{3} \mathrm{O}_{(\mathrm{aq})}^{+} \\
& \equiv \mathrm{MH}+\mathrm{H}_{2} \mathrm{O} \stackrel{\mathrm{pK}_{2}}{\rightleftharpoons}=\mathrm{MO}^{-}+\mathrm{H}_{3} \mathrm{O}_{(\mathrm{aq})}^{+}
\end{aligned}
$$

Esses equilíbrios conduzem a três tipos de sítios superficiais, cuja maioria é composta por $\equiv \mathrm{MOH}_{2}{ }^{+}$em meio fortemente ácido, um anfotérico $\equiv \mathrm{MOH}$ em região de neutralidade e outro $\equiv \mathrm{MO}^{-}$em meio fortemente básico. $\mathrm{pK}_{1}$ e $\mathrm{pK}_{2}$ são $\sim 5$ e $\sim 10$ para a magnetita. Dessa forma, há também maior possibilidade de interação, por meio de ligações de hidrogênio, entre BPA e superfície das nanopartículas de $\mathrm{Fe}_{3} \mathrm{O}_{4}$ em pH's próximos da neutralidade, onde $\equiv \mathrm{MOH}$ e $\mathrm{BPAH}_{2}$ predominam.

Esses resultados corroboram com os dados discutidos previamente. Conforme mostrado nas isotermas de adsorção, as inclinações iniciais são bem ajustadas pelos dois modelos (Langmuir e Freundlich). Essa inclinação depende das constantes que são relacionadas com a capacidade de adsorção. Assim, uma inclinação pronunciada pode ser usada como uma indicação da extensão ou afinidade entre adsorvato e adsorvente. De acordo com as propriedades dos adsorventes e adsorvatos, vários mecanismos de 
interação são possíveis: interação iônica, interação polar, transferência de carga, interações de London e interações de van der Waals. Em geral, levando-se em conta o balanço de forças atrativas entre adsorventes e asdsorvatos, as interações de van der Waals (o que inclui as interações $\pi-\pi$ ) são as dominantes, conforme é proposto para o BPA, molécula de hidrofobicidade considerável.

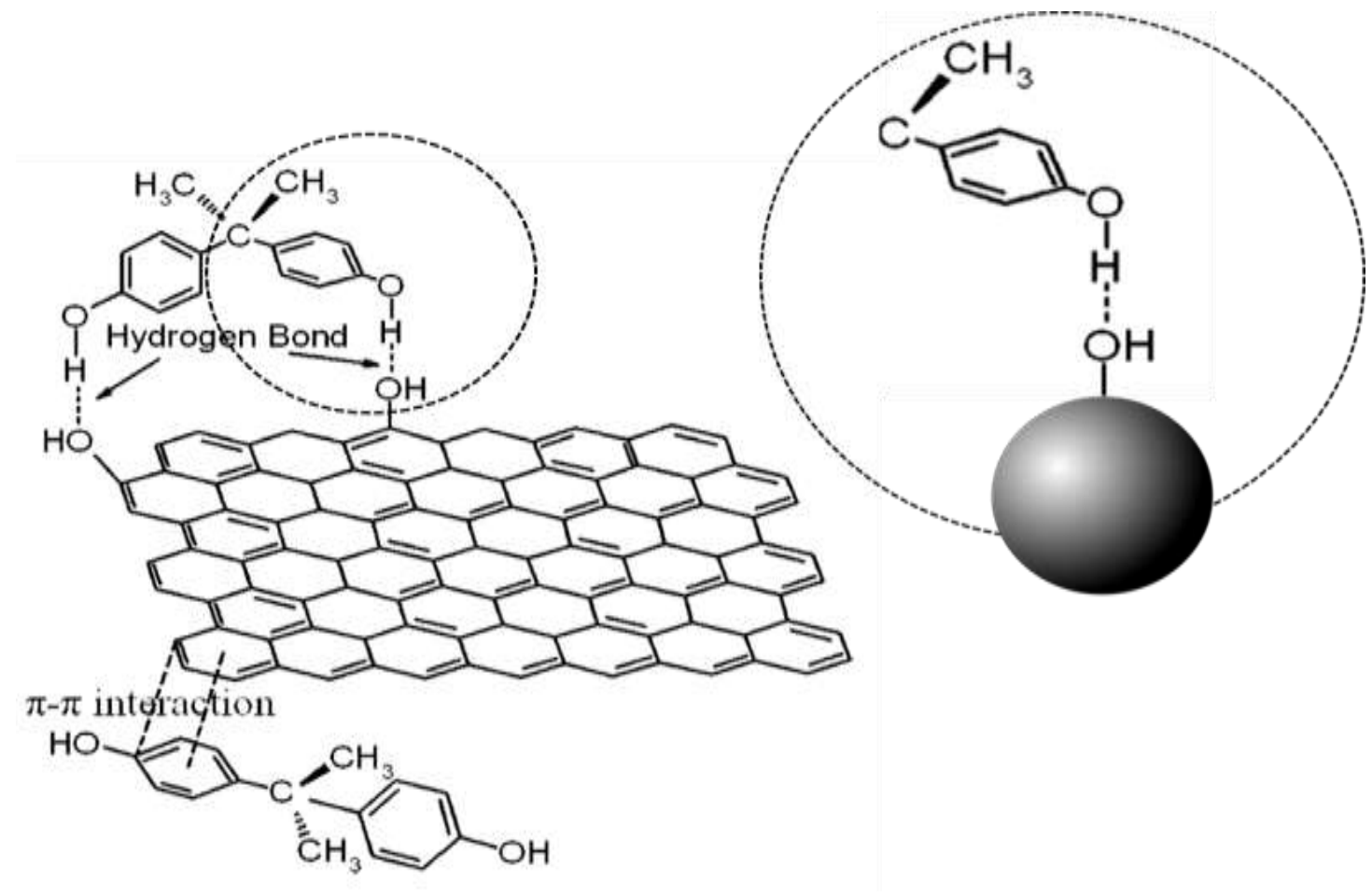

Figura 27 - Demonstração das interações de van der Wals entre o BPA e o carvão magnético. 


\section{CONCLUSÃO}

A impregnação de $\mathrm{Fe}_{3} \mathrm{O}_{4}$ no carvão ativado suporte, produziu um material magnético escuro, com características magnéticas diferentes do carvão ativado precursor. Esta impregnação foi confirmada pela comparação com valores indexados para a magnetita por difração de raios $\mathrm{X}$. O teor de ferro impregnado, na forma de $\mathrm{Fe}_{3} \mathrm{O}_{4}$, medido por ICP - OES, apresentou-se maior para o CAMG B do que para o CAMG A. Dado que foi corroborado em análises posteriores.

A microscopia eletrônica de varredura (MEV) demonstrou que o carvão ativado A apresentou poros maiores que o carvão B. Fato que poderia influenciar tanto na quantidade de magnetita $\left(\mathrm{Fe}_{3} \mathrm{O}_{4}\right)$ impregnada na superfície do carvão suporte quanto nas características de adsorção do carvão magnético produzido. Além disso, a análise de MEV revelou que a impregnação com $\mathrm{Fe}_{3} \mathrm{O}_{4}$ ocorre mais na superfície do carvão ativado do que propriamente nos poros do mesmo. Também foi revelado que na superfície do CAMG B ocorreu uma diminuição dos poros sugerindo uma maior obstrução dos mesmos provocada pelo óxido de ferro suportado na superfície do CAMG B em comparação com o CAMG A.

O resultado da análise de magnetização demonstrou que as duas amostras de carvão magnético (CAMG A e CAMG B) apresentaram características superparamagnéticas e que a origem desta magnetização ocorre unicamente pela presença das nanopartículas de óxido de ferro. O teor estimado de ferro na forma de magnetita, aproximou-se daquele determinado na dosagem por ICP - OES.

As medidas de área de superfície dos carvões ativados e dos carvões magnéticos utilizando BET demonstraram que, a impregnação com nanopartículas com óxido de 
ferro diminui o valor da área superficial do carvão e que um maior volume dos poros proporciona mais impregnação de material magnético no carvão ativado.

Para a determinação do BPA em amostras padrão, foi verificado que o comprimento de onda em $277 \mathrm{~nm}$ apresentou-se mais adequado para uma maior faixa de $\mathrm{pH}$, permitindo a construção de uma curva de calibração de $\mathrm{R}^{2}=0,9999$.

Isto a proporcionou a elaboração de isotermas de adsorção para avaliar a eficiência de remoção de BPA das amostras contaminadas pelos carvões magnéticos elaborados, além da avaliação dos parâmetros do tempo de contato entre os carvões elaborados e as soluções contaminadas com BPA. Este estudo demonstrou que, na adsorção do BPA pelo carvão magnético, tanto a agitação por vórtex quanto a agitação por tombamento seguem o modelo matemático de Freundlich. E que a agitação tombamento apresentou uma maior eficiência de remoção de BPA pelo carvão magnético (CAMG A).

Na comparação da adsorção entre os dois carvões, o estudo demonstrou uma maior eficiência de remoção do CAMG A em relação ao CAMG B, fato que pode ser atribuído ao tamanho dos poros do carvão suporte A utilizado na elaboração deste mesmo carvão magnético. De modo geral, os dois carvões se mostraram bem eficientes na remoção de BPA.

Em termos cinéticos, tanto a agitação vórtex quanto o tombamento, apresentaram tempo de contato de pseudo de segunda ordem. Porém, a agitação tombamento apresentou uma curva menos inclinada com saturação, situação diversa daquela apresentada na agitação vórtex.

A maior eficiência de remoção demonstrada pelo CAMG A em comparação com o CAMG B, atribuiu-se aos poros maiores do CAMG A e a maior ocupação dos sítios de adsorção pelo óxido de ferro, no CAMG B, utilizado para tornar o carvão suporte 
magnético. Parâmetros como tamanho e volume dos poros do carvão ativado são aspectos que influenciam tanto na eficiência de remoção quanto na cinética de adsorção dos carvões magnéticos adsorventes.

O estudo da influência do pH mostrou que a máxima eficiência de remoção de BPA é atingida numa região de pH ácido a neutro (onde o BPA se encontra totalmente protonado), caindo drasticamente em $\mathrm{pH} 8$ (no qual o BPA começa a desprotonar), e caindo mais ainda em $\mathrm{pH} 12$ (BPA totalmente desprotonado). Comportamento demonstrado nas curvas de especiação apresentadas no trabalho para a molécula de BPA. As interações entre as moléculas orgânicas, com duplas ligações aromáticas em superfícies carbonáceas, podem ser explicadas pelo mecanismo de interações $\pi-\pi$, visto que a estrutura do BPA apresenta dois anéis aromáticos com elétrons $\pi$ que interagem com a superfície do carvão ativado por meio de acoplamento $\pi-\pi$. E admitindo que a superfície das nanopartículas de $\mathrm{Fe}_{3} \mathrm{O}_{4}$ podem assumir comportamento como ácido diprótico, também podem ocorrer interações de hidrogênio entre as nanopartículas e as hidroxilas do BPA, contudo existe uma predominância por interações do tipo $\pi-\pi$.

De forma geral, este trabalho mostrou a importância da investigação da natureza micrométrica e manométrica das propriedades dos adsorventes de carvão utilizados para a remediação ambiental. As perspectivas futuras visam a necessidade de se produzir um adsorvente fabricado a partir de biomassa e realizar testes semelhantes com o intuito de verificar a sua potencial eficiência. 


\section{REFERÊNCIAS}

${ }^{1}$ Da Silva CGA, Collins CH. Aplicações de cromatografia líquida de alta eficiência para o estudo de poluentes orgânicos emergentes. Química Nova 2011; 34(4):665-676;

2 Zhuang $\mathrm{Y}$ et al. Spetrophotometric and high performace liquid chromatographic methods for sensitive determination of bisphenol A. Spectrochimica Acta Part A: Molecular and Biomolecular Spectroscopy 2014;122:153-157. Disponível em: http://dx.org/10.1016/j.saa.2013.11.015

3 Zhu LL, Cao YH, Cao GQ. Preparation and Application of Core-shell Magnetic Imprinted Nanoparticles for Bisphenol A Chin J Anal Chem, 2013;41(11):1724-1728.

${ }^{4}$ Cela-Pérez MC et al. Synthesis and characterization of bisphenol-A imprinted polymer as a selective recognition receptor. Analytica Chimica Acta 2011;706:275-284.

${ }^{5} \mathrm{Yu} \mathrm{C}$ et al. Chitosan- $\mathrm{Fe}_{3} \mathrm{O}_{4}$ nanocomposite based electrochemical sensors for the determination of bisphenol A. Electrochimica Acta 2011;56:9056- 9063.

${ }^{6}$ Chen $X$ et al. Determination of bisphenol A in water via inhibition of silver nanoparticles-enhanced chemiluminescence. Analytica Chimica Acta 2011; 689:92-96.

${ }^{7}$ Molina-García L et al. Analysis of Bisphenol A in milk by using a multicommuted fluorimetric sensor. Talanta 2012;96:195- 201.

8 Ragavan KV, Ratogi NK, Thakur MS. Sensors and biosensors for analysis of bisphenol-A. Trends Analytical Chemistry 2013;52:248-260. Disponível em: http://dx.doi.org/10.1016/j.trac.2013.09.006

${ }^{9}$ Ghiselli G, Jardim WF. Interferentes endócrinos no ambiente. Quim. Nova 2007; 30:(3):695-706. 
${ }^{10}$ Del Pup L et al.Carcinogenetic mechanisms of endocrine disruptors in female cancers (Review) Oncology Reports. 2016;36: 603-612.

11 Mita DG.Endocrine Disruptors: a Real Concern for Humans? The Open Biotechnology Journal. 2016; 10:3-19.

${ }^{12}$ Yin $\mathrm{N}$ et al. Assessment of Bisphenol A (BPA) neurotoxicity in vitro withm mouse embryonic stem cells. Journal of Environmental Science. 2015; 36: 181-87 .

${ }^{13}$ Jiang Y et al. BPA-induced DNA hypermethylation of the master mitochondrial gene PGC-1a contributes to cardiomyopathy in male rats. Toxicology. 2015; 329: 21-31.

14 Johnson AS et al. Effects of developmental exposure to bisphenol A on spatial navigational learning and memory in rats: A CLARITY-BPA study. Hormones and Behavior 2016; 80: 139-148.

${ }^{15}$ Mao Z et al. Paternal BPA exposure in early life alters Igf2 epigenetic status in sperm and induces pancreatic impairment in rat offspring. Toxicology Letters.2015; 238: $30-38$.

${ }^{16}$ Fernández MF et al. Bisphenol A and other phenols in human placenta from children with cryptorchidism or hypospadias. Reproductive Toxicology. 2016; 59:89-95.

17 Paulose $\mathrm{T}$ et al. Estrogens in the wrong place at the wrong time: Fetal BPA exposureand mammary cancer. Reproductive Toxicology. 2015; 54: 58-65.

18 Nie L et al. Effects of bisphenol A on key enzymes in cellular espiration of soybean seedling roots. Environmental Toxicology and Chemistry. 2015; 34(10):2363-2369.

19 Andra SS et al. Biomonitoring of human exposures to chlorinated derivatives and estructural analogs of bisphenol A. Environment International. 2015; 85:352-379. 
${ }^{20}$ Yamazaki E et al. Bisphenol A and other bisphenol analogues including BPS and BPF in surface water samples from Japan, China, Korea and India. Ecotoxicology and Environmental Safety 2015; 122:565-572.

${ }^{21}$ Chen WY et al. Assessing bisphenol A (BPA) exposure risk from long-term dietary intakes in Taiwan. Science of the Total Environment. 2016; 543: 140-146.

${ }^{22}$ Huang R et al. Heterogeneous sono-Fenton catalytic degradation of bisphenol A by $\mathrm{Fe}_{3} \mathrm{O}_{4}$ magnetic nanoparticles under neutral condition. Chemical Engineering Journal 2012;197:242-249.

${ }^{23}$ Yang $\mathrm{X}$ et al. Au/carbon as Fenton-like catalysts for the oxidative degradation of Bisphenol A. Applied Catalysis B: Environmental 2013;134- 135:145- 152.

${ }^{24}$ Tsai WT et al. Photodegradation of bisphenol-A in a batch $\mathrm{TiO} 2$ suspension reactor. Journal of Hazardous Materials 2009; 168:269-275.

${ }^{25}$ Chang HS et al. The methods of identification, analysis, and removal of endocrine disrupting compounds (EDCs) in water. Journal of Hazardous Materials. 2009;172:112.

26 Zhu LL et al. Preparation and Application of Core-shell Magnetic Imprinted Nanoparticles for Bisphenol A. Chin J Anal Chem, 2013; 41(11):1724-1728.

27 Yang $\mathrm{J}$ et al. Molecularly imprinted polymer microspheres prepared by Pickering emulsion polymerization for selective solid-phase extraction of eight bisphenols from human urine samples. Analytica Chimica Acta. 2015; 872: 35-45.

${ }^{28}$ Guo W et al. Selective adsorption and separation of BPA from aqueous solution using novel molecularly imprinted polymers based on kaolinite/Fe3O4 composites. Chemical Engineering Journal. 2011;171:603-611. 
${ }^{29}$ Pan J et al. Molecularly imprinted polymers based on magnetic fly-ash-cenosphere composites for bisphenol A recognition. J. Mater. Chem.2011;21: 15741.

$30 \mathrm{Xu} \mathrm{J}$ et al. Decontamination of Bisphenol A from Aqueous Solution by GraphenAdsorption. Langmuir 2012; 28:8418-8425.

${ }^{31}$ Katsigiannis A et al. Removal of emerging pollutants through Granular Activated Carbon. Chemical Engineering Journal 2015; 280:49-57.

${ }^{32}$ Liang $\mathrm{L}$ et al. Occurrence of bisphenol $\mathrm{A}$ in surface and drinking waters and its physicochemical removal technologies. Front. Environ. Sci. Eng. 2015;9(1):16-38.

${ }^{33}$ Liu $\mathrm{G}$ et al. Adsorption of bisphenol A from aqueous solution onto activated carbons with different modification treatments. Journal of Hazardous Materials 2009; 164:12751280.

${ }^{34}$ Tang S et al. Removal of bisphenol A in water using an integrated granular activated carbono preconcentration and dielectric barrier discharge degradation treatment. Thin Solid Films 2012; 521:257-260.

${ }^{35}$ Ravi S et al. Sustainable carbon nanomaterials: Recent advances and its applications in energy and environmental remediation. Journal of Environmental Chemical Engineering. 2016; 4: 835-856.

${ }^{36} \mathrm{Han} \mathrm{Z}$ et al. Magnetite impregnation effects on the sorbent properties of activated carbons and biochars. Water research 2015; 70:394-403.

${ }^{37}$ Gómez-Pastora J, Bringas E., Ortiz I, Recent progress and future challenges on the use of high performance magnetic nano-adsorbents in environmental applications, Chem. Eng. J. 2014; 256:187-204. 
${ }^{38}$ Ngomsik AF, Bee A, Draye M, Cote G, Cabuil V. Magnetic nano- and microparticles for metal removal and environmental applications: a review, R. Chimie 2005;(8):963-970.

39 Yazdinezhad SR et al. Single-step extraction and cleanup of bisphenol A in soft drinks by hemimicellar magnetic solid phase extraction prior to liquid chromatography/tandem mass spectrometry. 2013;778:31- 37.

40 Kumar A et al. Spion/ $\beta$-cyclodextrin core-shell nanostructures for oil spill remediation and organic pollutant removal from waste water. Chemical Engineering Journal 2015;280:175-187.

${ }^{41} \mathrm{Pan} \mathrm{J}$ et al. Synthesis of chitosan $/{ }^{\gamma}-\mathrm{Fe}_{2} \mathrm{O}_{3} / \mathrm{fly}$-ash-cenospheres composites for the fast removal of bisphenol A and 2,4,6-trichlorophenol from aqueous solutions. Journal of Hazardous Materials 2011;190:276-284.

${ }^{42}$ Park HS et al. Activated carbons impregnated with iron oxide nanoparticles for enhanced removal of bisphenol A and natural organic matter. Journal of Hazardous Materials 2015;286: 315-324.

${ }^{43}$ Mohan D et al. Development of magnetic activated carbon from almond shells for trinitrophenol removal from water. Chemical Engineering Journal 2011; 172:11111125 .

44 Park HS et al. Activated carbons impregnated with iron oxide nanoparticles for enhanced removal of bisphenol A and natural organic matter. Journal of Hazardous Materials 2015;286 315-324.

45 Kakavandi $\mathrm{B}$ et al. Synthesis and properties of $\mathrm{Fe}_{3} \mathrm{O}_{4}$-activated carbon magnetic nanoparticles for removal of aniline from aqueous solution: equilibrium, kinetic and thermodynamic studies. Iranian Journal of Environmental Health Sciences \& Engineering 2013;10:19. 
${ }^{46} \mathrm{Li} \mathrm{Z}$ et al. Preparation of magnetic separable $\mathrm{CoFe}_{2} \mathrm{O}_{4} / \mathrm{PAC}$ composite and the adsorption of bisphenol A from aqueous solution. Journal of Saudi Chemical Society 2014;18:208-213.

${ }^{47}$ Mohan D et al. Development of magnetic activated carbon from almond shells for trinitrophenol removal from water. Chemical Engineering Journal 2011; 172: 11111125.

${ }^{48}$ Rodovalho FL. Elaboração de Nanosorbentes Magnéticos à Base Nanopartículas de $\mathrm{Co}_{0,5} \mathrm{Mn}_{0,5} \mathrm{Fe}_{2} \mathrm{O}_{4}$ Funcionalizadas com Polidimetilsiloxano como Protótipos para Remediação de Águas Contaminadas com Derivados de Combustíveis Fósseis. 2015; Dissertação.

49 Campos AFC et al. Nanoparticles superficial density of charge in electric doublelayered magnetic fluid: A conductimetric and potentiometric approach. European Physical Journal E. 2001; 6(1): 29-35.

${ }^{50}$ Del Olmo et al. Determiation of bisphenol A (BPA) in the presence of phenol by firstdeivative fluorescence following micro liquid-liquid extraction (MLLE). Talanta 2000;50:1141-1148.

${ }^{51}$ Atkins P et al. Físico-Química. Nona Edição. Rio de Janeiro: LTC.2012:2. 